Iranian Journal of Breast Diseases. 2022;14(1):49-63.
Original Article

\section{Identification of Prognostic Genes in HER2-enriched Breast Cancer by Gene Co-expression Network Analysis}

\author{
Darzi $\mathbf{M}^{1}$, Gorgin $\mathbf{S}^{\mathbf{1}}$, Majidzadeh-A $\mathbf{K}^{2}$, Esmaeili $\mathbf{R}^{2^{*}}$ \\ ${ }^{1}$ Department of Electrical Engineering and Information Technology, Iranian \\ Research Organization for Science and Technology (IROST), Tehran, Iran \\ ${ }^{2}$ Genetics Department, Breast Cancer Research Center, Motamed Cancer \\ Institute, ACECR, Tehran, Iran
}

Receive: $31 / 1 / 2021$

Accepted: 27/3/2021

*Corresponding Author: esmaeili.rezvan@gmail.com

Ethics Approval: Not Applicable

\begin{abstract}
Introduction: HER2-enriched subtype of breast cancer has a worse prognosis than luminal subtypes. Recently, the discovery of targeted therapies in other groups of breast cancer has increased patient survival. The aim of this study was to identify genes that affect the overall survival of this group of patients based on a systems biology approach.

Methods: Gene expression data and clinical information on 58 patients with HER2-enriched cancer were downloaded from The Cancer Genome Atlas (TCGA). Co-expression modules were identified using the weighted gene co-expression network analysis (WGCNA). The Cox regression was used to determine the modules that had a significant relationship with the overall survival (OS) endpoint. Single-gene survival analysis was performed within the selected module. Finally, functional annotation to explore the significance of genes was performed using the Database for Annotation, Visualization, and Integrated Discovery (DAVID).
\end{abstract}

Results: Of the six identified co-expression modules, two had significantly poor prognoses. Single-gene survival analysis showed that $39 \%$ of genes in the selected modules were identified as significant. The genes were mainly related to the biological pathways such as Ubiquitin-mediated proteolysis and RNA degradation. CHAMP1, PPP1R26, PRRC2B, KANSL3, and $A N A P C 2$ were identified as the 5 most important genes associated with reduced OS, in order of significance.

Conclusion: The systems biology approach can provide appropriate results relate to patient survival analysis. In this study, some genes were identified to be used as prognostic biomarkers in experimental studies related to the OS in the HER2-enriched subgroup. These genes can be considered potential candidates for therapeutic targets in this group of patients.

Keywords: HER2-enriched Breast Cancer, WGCNA, Co-expression Network, TCGA 


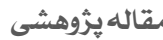

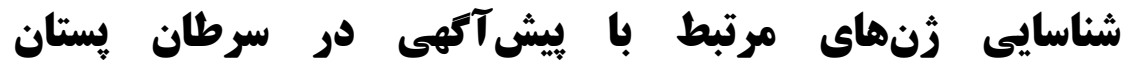
Her2-enriched با استفاده از تجزيه و تحليل شبكه همبيانى زنى

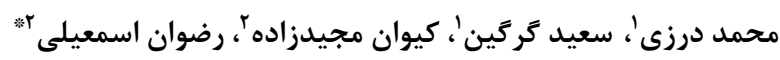
' يزووهشكده برق و فناورى اطلاعات، سازمان يزوهشهاى علمى و صنعتى ايران، تهران، ايران

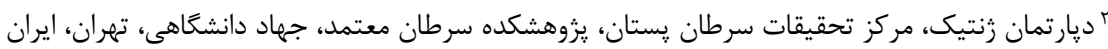

فصلنامه بيمارى هاى يستان ايران

$1 \varepsilon \cdots ! 1 \varepsilon(1): \varepsilon q-7 r$
OU ?

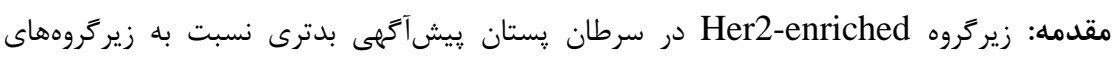

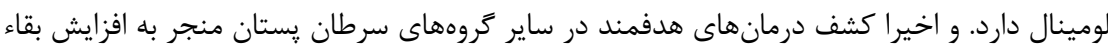

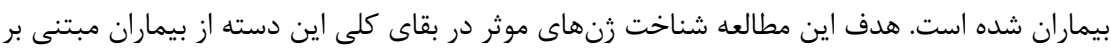
زيستشناسى سامانهاى است.

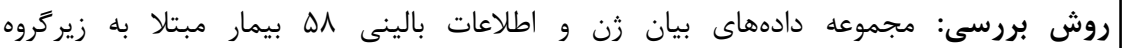
Her2-enriched

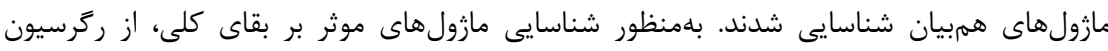

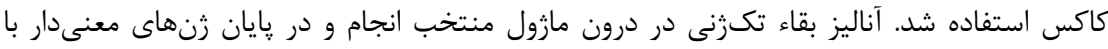

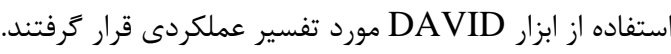

يافتهها: از ميان شش مازول همبيان شناسايىشده، دو مازول به طور معنىدار با بِيشآكَهى بدتر در

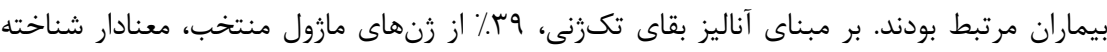

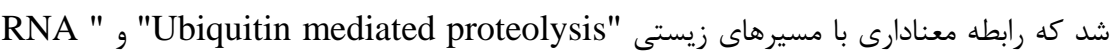
" degradation بNAPC2

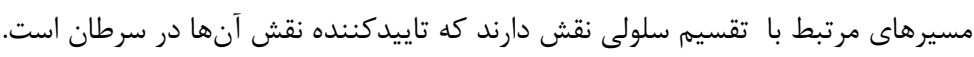
نتيجهَيرى: رويكرد زيستشناسى سامانهاى مى تواند نتايج مناسبى در تحليل بقاء بيماران داشته

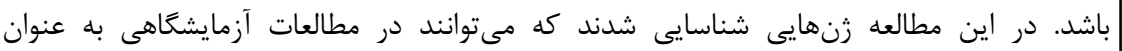

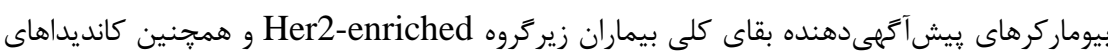

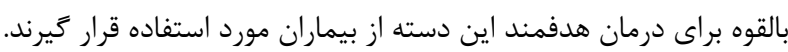
وازههاى كليدى: سرطان، زيستشناسى سامانهاى، شبكههاى وزندار، شبكههاى همبيانى، WGCNA ،Her2-enriched
تاريخ ارسال: : إريخ :

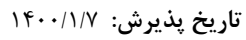

"نويسنده مسئول: esmaeili.rezvan@gmail.com 
كانه منفى" يا بازال rا شامل •r-• (1\% از تمام موارد

سرطان يستان است كه متاسفانه در زنان جوان به ويزه در

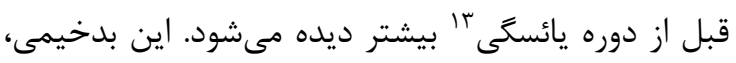

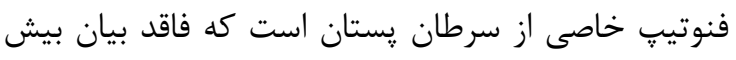

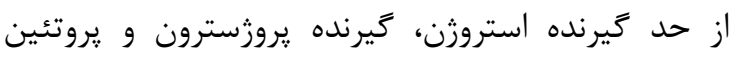

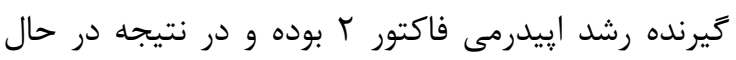

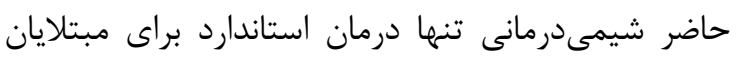

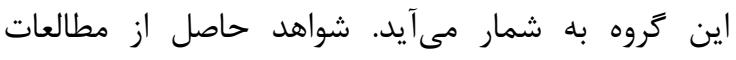

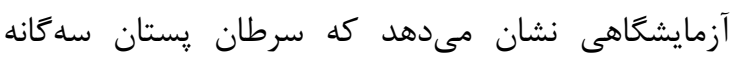

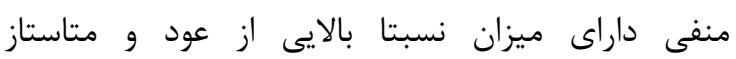

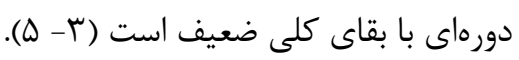
يكى ديخر از زيركروههاى سرطان HER2-enriched

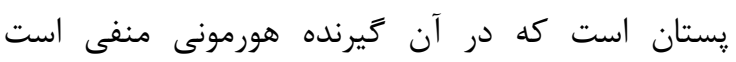
(كيرنده استروزن و كيرنده يروزسترون منفى) و

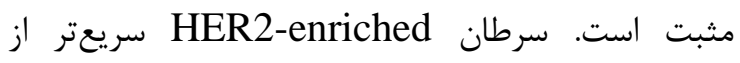

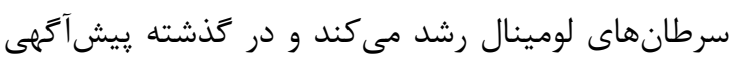

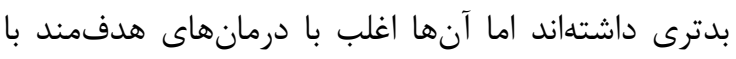

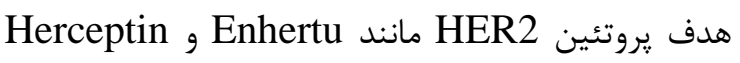

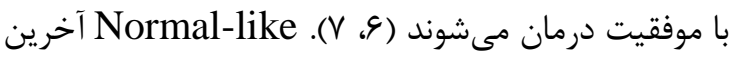

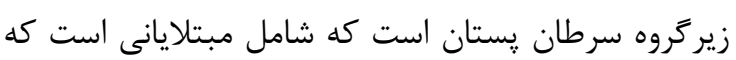

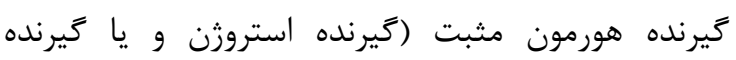

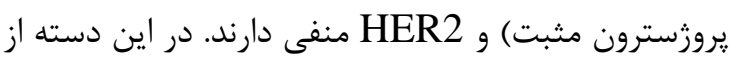
مبتلايان به سرطان پِتان، سطح بروتئين

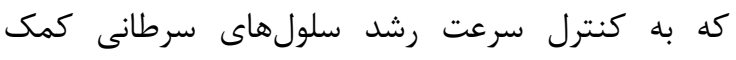
مى كند. شرايط اين كروه شبيه كروه لومينال A

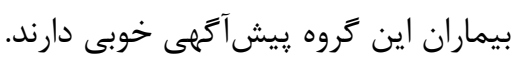

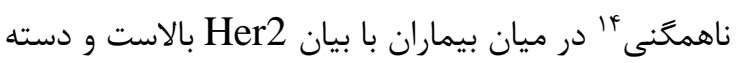

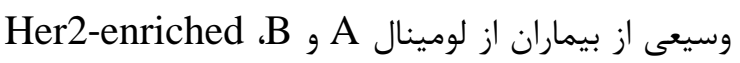

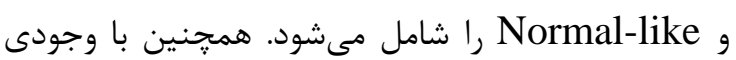

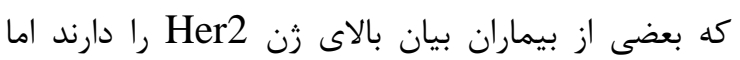

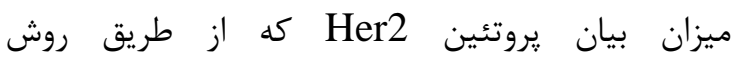

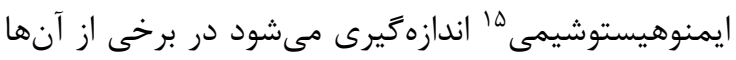

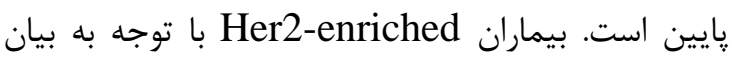
بالاى زنهاى ديخرى نظير زنهاى مسير گيرنده فاكتور

\footnotetext{
${ }^{11}$ Triple Negative Breast Cancers (TNBC)

${ }^{12}$ Basal-Like

${ }^{13}$ Pre-menopausal

${ }^{14}$ Heterogeneity

${ }^{15}$ Immunohistochemistry (IHC)
}

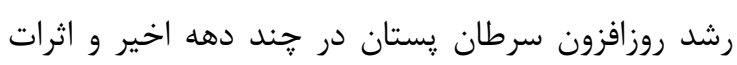

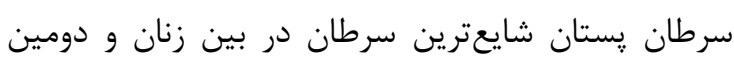

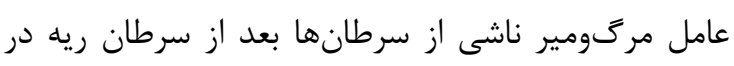

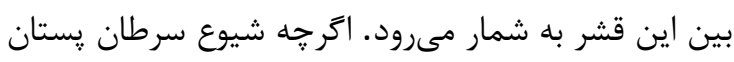

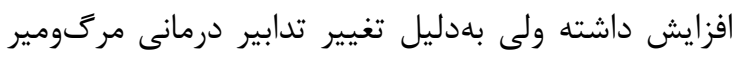

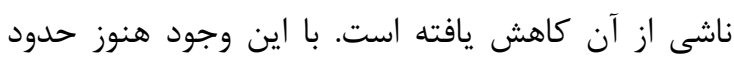

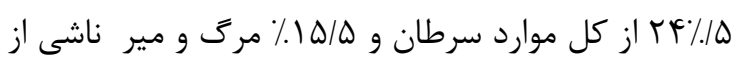

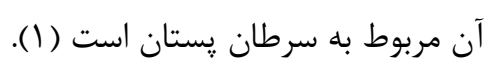

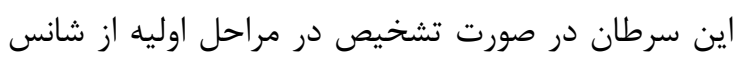

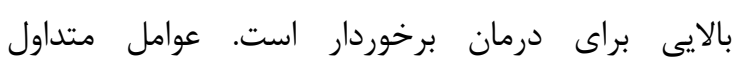

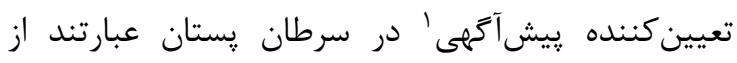

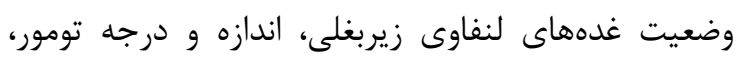

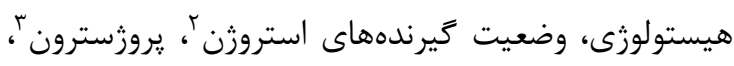

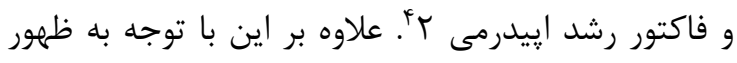

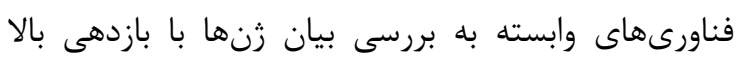

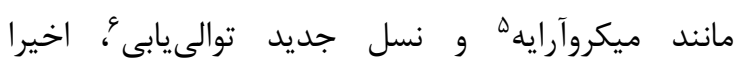
تقسيمبندى مولكولى نيز در سرطان يستان انجام شده

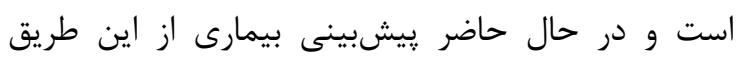

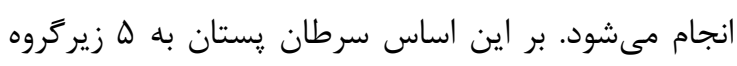

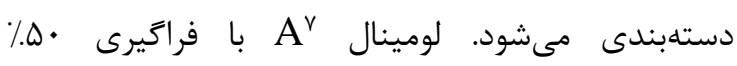
شايعترين سرطانهاى مهاجم يستان را تشكيل مىدهد.

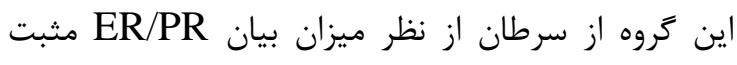

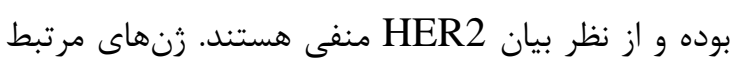

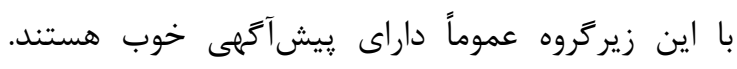

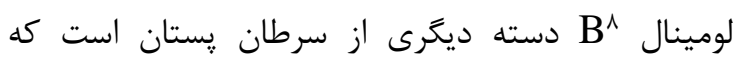

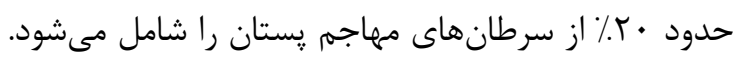

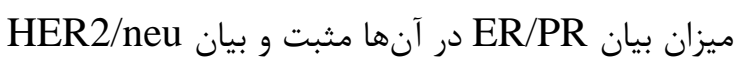

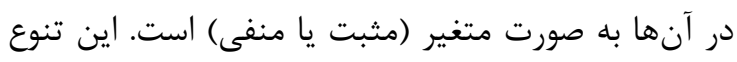

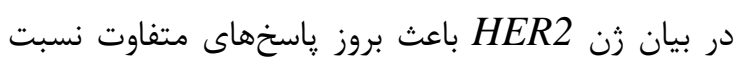

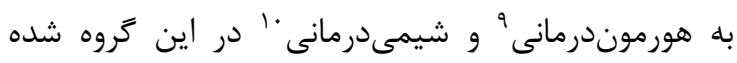

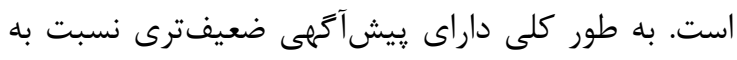

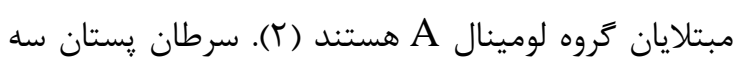

\footnotetext{
${ }^{1}$ Prognosis

${ }^{2}$ Estrogen Receptor (ER)

${ }^{3}$ Progesterone Receptor (PR)

${ }^{4}$ Human Epidermal growth factor Receptor 2 (HER-2)

${ }^{5}$ Microarray

${ }^{6}$ Next Generation Sequencing (NGS)

${ }^{7}$ Luminal A

${ }^{8}$ Luminal B

${ }^{9}$ Endocrine Therapy

${ }^{10}$ Chemotherapy
} 
قرار مى گيرد. و در نهايت زنهاى موجود در مازولهاى

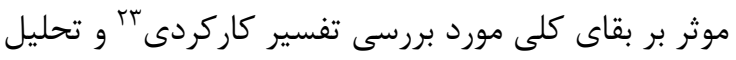

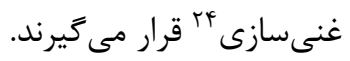

\section{مواد و روشها}

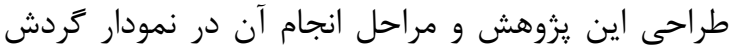
كار در شكل ا ارايه شده است. بر اين اساس مراس مراحل

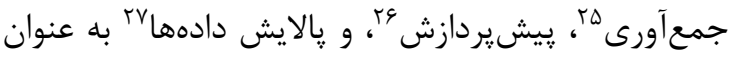

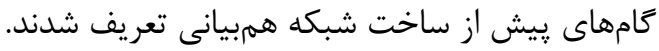

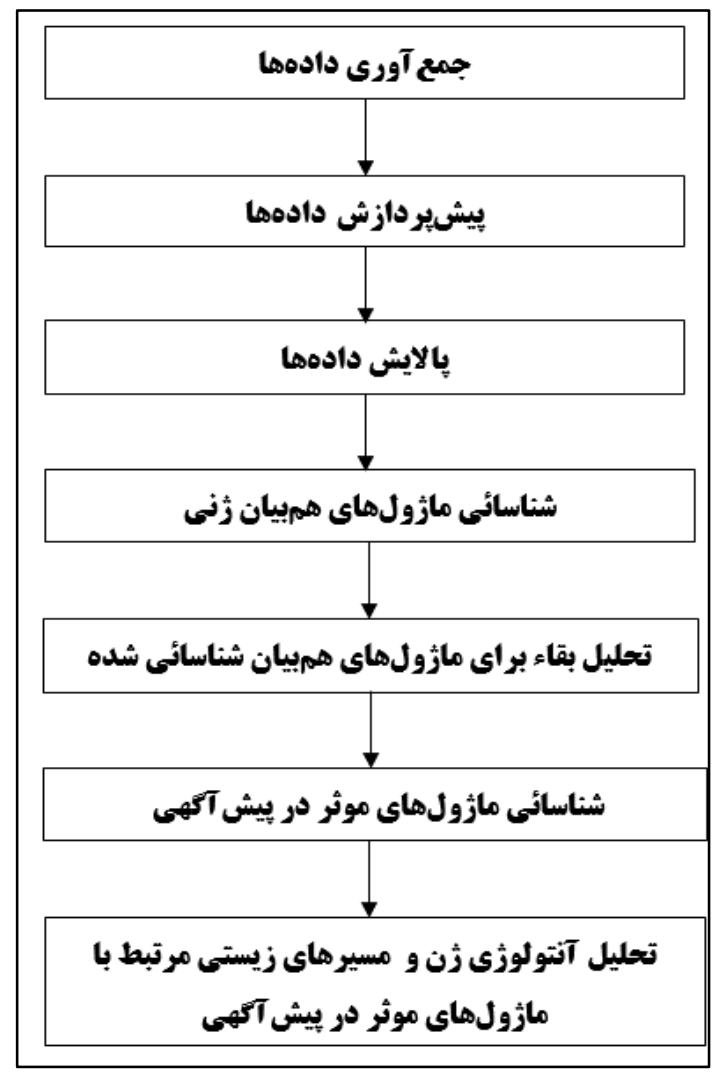

شكل ا: نمودار تردش كار مراحل اجراى يزؤهش

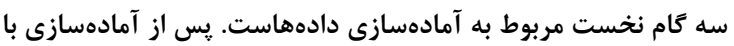

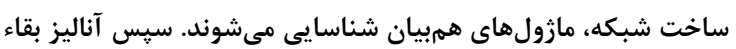

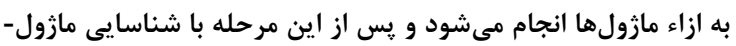

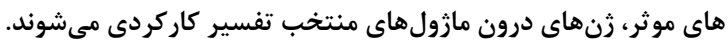

شبكه همبيانى رنى بر اساس دادههاى حاصل از اجراى سه

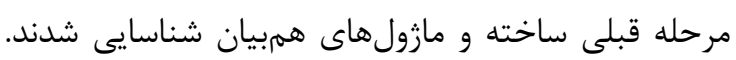
يس از ساخت شبكه و شناسايى مازولها، آناليز بقاء به

\footnotetext{
${ }^{23}$ Functional Annotation Analysis

${ }^{24}$ Enrichment Analysis

${ }^{25}$ Data Collection

${ }^{26}$ Data Preprocessing

${ }^{27}$ Data Filtering
}

رشد إيدرمال19 و تايروزين كيناز"ا كانديداى ياسخ به درمان هاى جديد هستند. يكى از راهبردهايى كه در سالهاى اخير با كسترش هادي

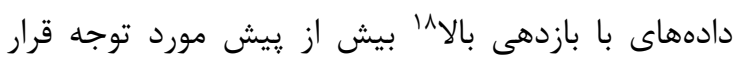
كرفته است استفاده از رويكرد زيستشناسى سامانهانى 19 براى تحليل برهمكنش زنها بر روى يكديگر و تاثير اين برهمكنش بر روى ويزگى هاى بالينى بيماران بوده است.

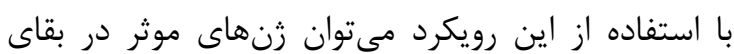

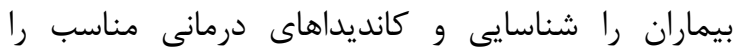

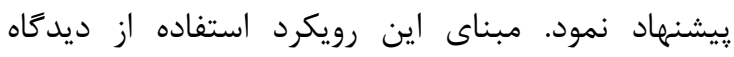

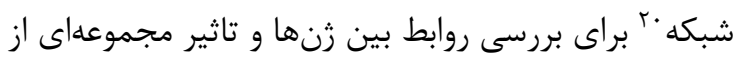

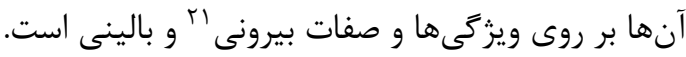
تحليل شبكه همبيان رنى وزني وندار (WGCNA

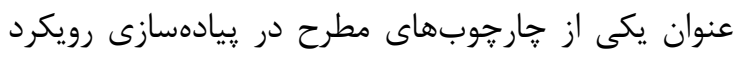

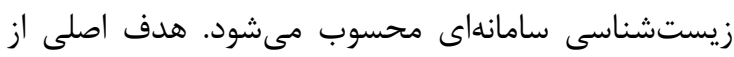
طراحى اين جارجوب تحليل رفتار همبيانى مجموعهاى از

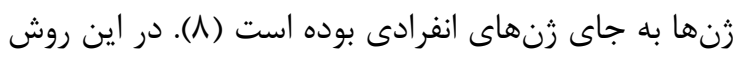

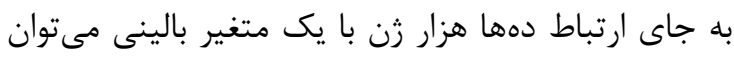

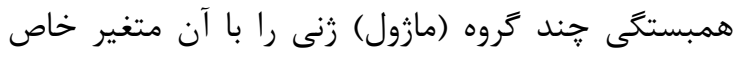

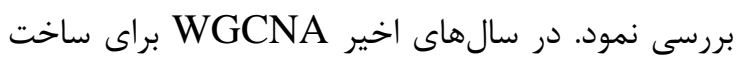

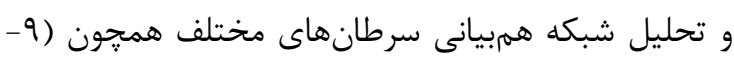

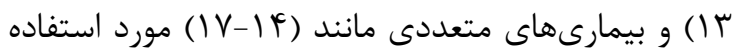

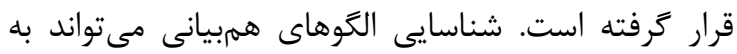

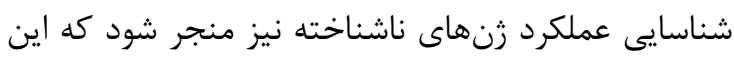
امكان با عنوان guilt-by-association (GBA) شناخته مىشود.

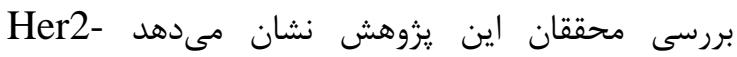

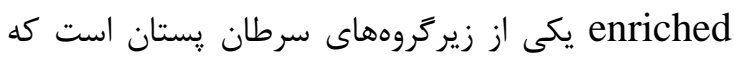
شبكه برهمكنش زنهاى آن مورد بررسى قرار نكرفته

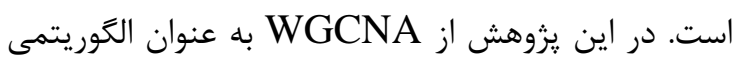

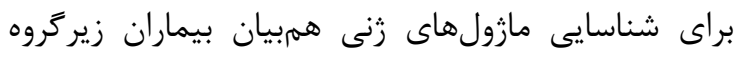

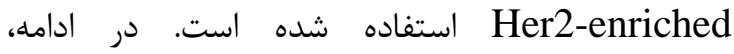

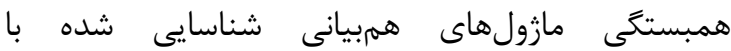
ويزگى هاى بالينى همجيون بقاى كلى بيماران مورد بررسى همى

\footnotetext{
${ }^{16}$ Epidermal growth factor Receptor

${ }^{17}$ Tyrosine kinase

${ }^{18}$ High-throughput

${ }^{19}$ System Biology

${ }^{20}$ Network Approach

${ }^{21}$ External Trait

${ }^{22}$ Weighted gene Co-expression Network Analysis
} 


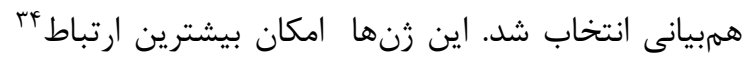
به ساير زنها را داشتند. كيفيت نمونهها و رنها با با استفاده

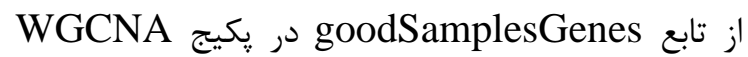
مورد بررسى قرار گرفت بهطورى كه زنهاى با واريانس صفر در تمامى نمونهها حذف شدند. ساخت شبكه همبيان زنى وزندار شبكه همبيان زنى زيرگروه Her2-enriched با استفاده

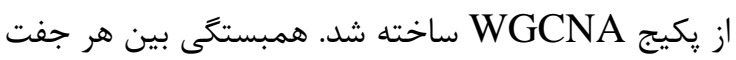

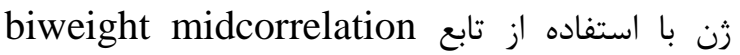
محاسبه شد. يايدارى (bicor) استفاده از اين روش در مقايسه با ضريب همبستكى ياسي

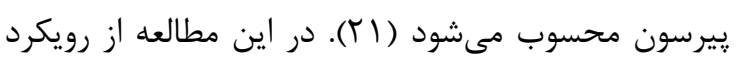

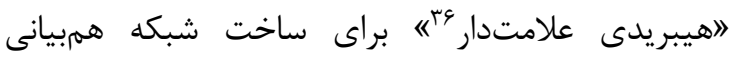

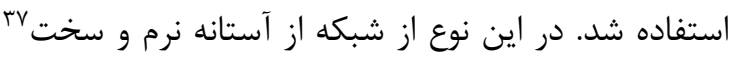

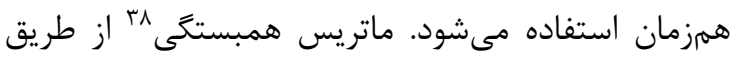

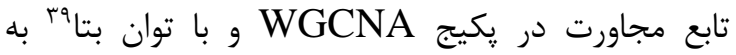

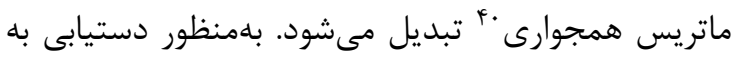

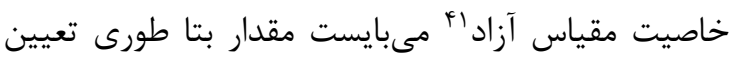
شود كه اين ويزگى در شبكه حاصل شود. در شبكه

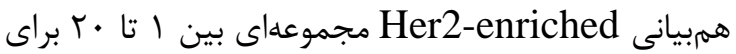
بتا، مورد بررسى قرار مى گيرد و در نهايت با در نظر گرفتن

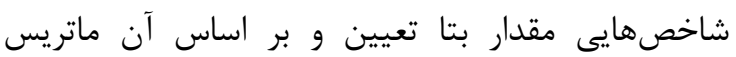
مجاورت ساخته مىشود. در گجارجوب WGCNA به منظور شناسايى خوشههاى زنى با بيشترين همبيانى از نسخه تعميميافتهمعيار

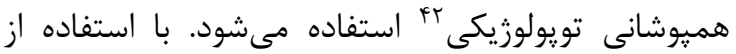
معيار هميوشانى توبولوزيكى علاوه بر محاسبه شباهت دو زن، همزمان شباهت زنهاى متصل به دو زن مذكور نيز

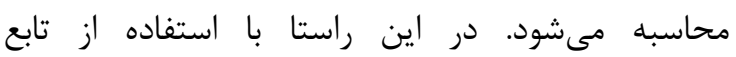
TOMsimilarity جديدى در ماتريس هميوشانى توبولوزيكى تبديل مىشوند. تمامى نهادههاى اين ماتريس مثبت بوده و خود

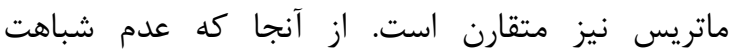

\footnotetext{
${ }^{34}$ Most Connected Genes

${ }^{35}$ Robustness

${ }^{36}$ Signed Hybrid Network

${ }^{37}$ Hard and Soft Thresholding

${ }^{38}$ Correlation Matrix

${ }^{39}$ Power $\beta$

${ }^{40}$ Adjacency Matrix

${ }^{41}$ Scale-free Network

${ }^{42}$ Generalized Version of Topological Overlap Measure (TOM)
}

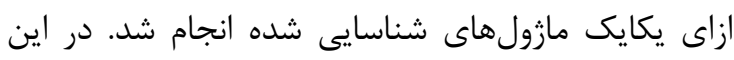

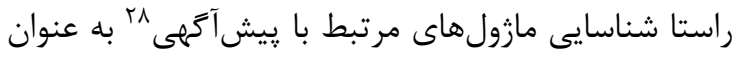

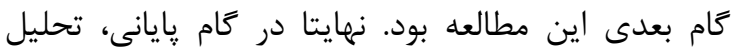

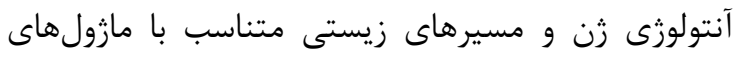

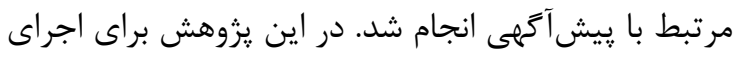

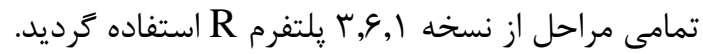

مجموعه داده و بيش يردازش دادهها

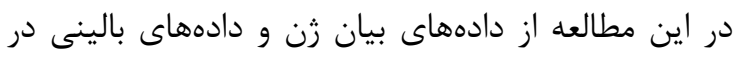

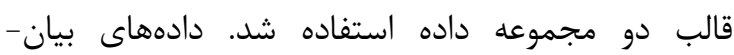

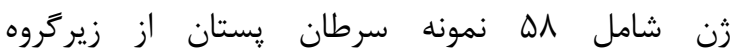
Her2-enriched

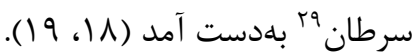
فايلهاى شمارش خوانش خام كه خدان خروجى ابزار HTSeq-Count

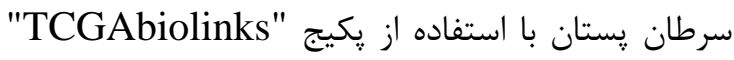

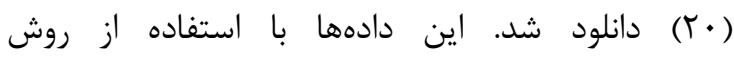

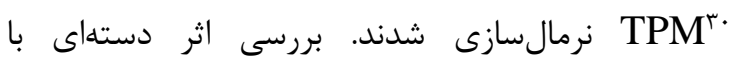

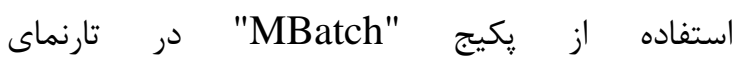
https://bioinformatics.mdanderson.org انجام شد. بر اساس نتايج حاصله از آناليز آنلاين اين تارنما، مجموعه

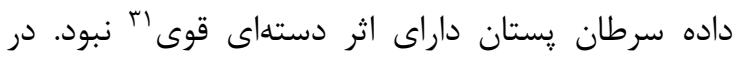

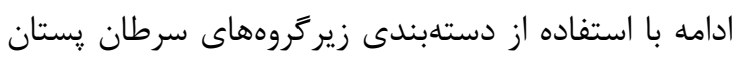

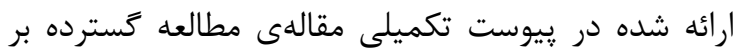

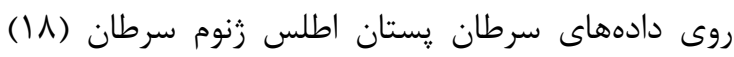

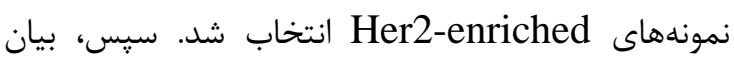

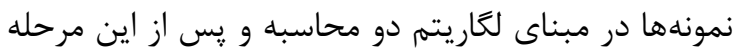

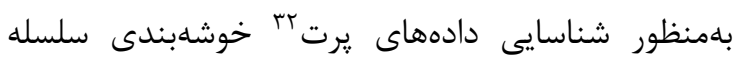

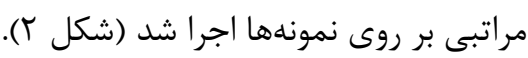

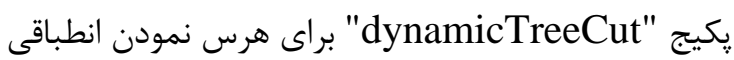

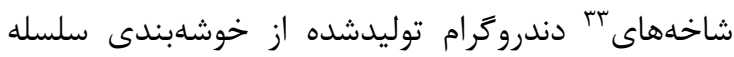

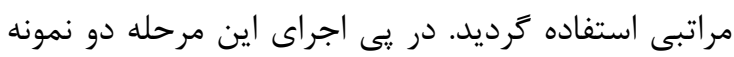

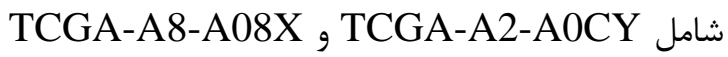
به عنوان داده يرت شناخته و حذف شدند. در اين مطالعه

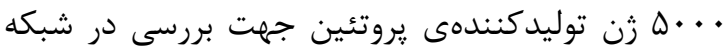

\footnotetext{
${ }^{28}$ Prognostic Modules

${ }^{29}$ The Cancer Genome Atlas (TCGA)

${ }^{30}$ Transcripts Per Million

${ }^{31}$ Strong Batch Effect

${ }^{32}$ Outlier

${ }^{33}$ Adaptive Branch Pruning
} 
جارجوب WGCNA با استفاده از ME هر مازول انجام

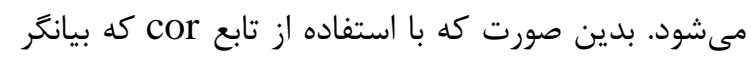
ضريب همبستگى پيرسون است، ميزان همبستخى بين ME محاسبه مىشود. در اين مطالعه ويزگَىهاى بالينى عبارتند

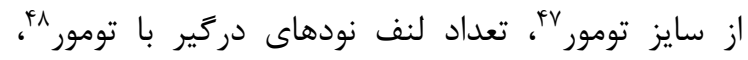

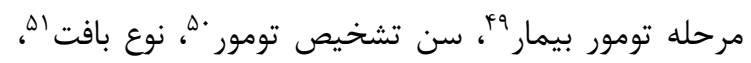

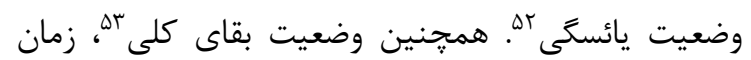

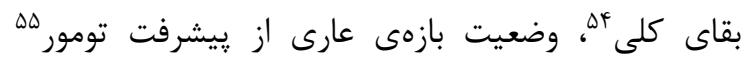

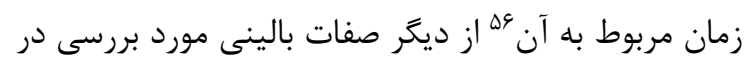
اين مطالعه بوده است.

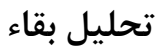

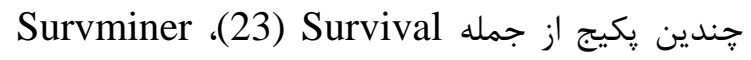

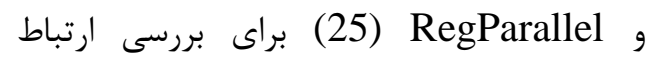

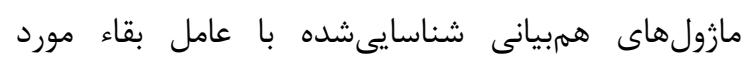
استفاده قرار كرفت. در اين قسمت نيز از

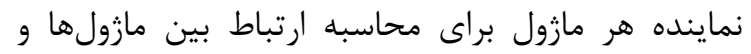

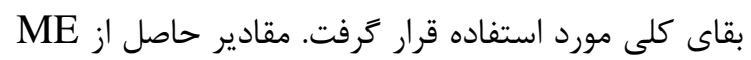
براى مازولها به دو دسته مثبت و منفى تقسيم شدند (T) (T). در اين راستا ركرسيون كاكس تكمتغيره و نمودار

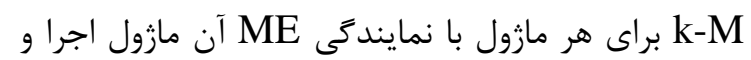

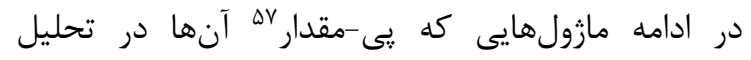

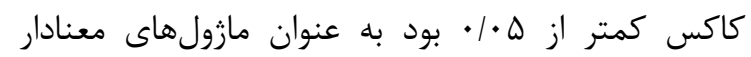

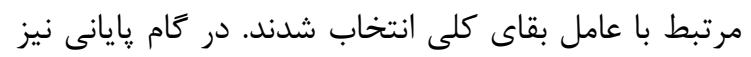

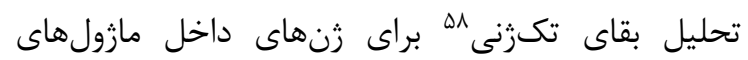

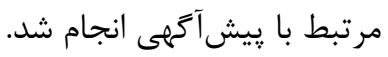

\section{آنتولوزنى زن و تحليل مسير هاى زيستى}

تحليل غنىسازى زنى

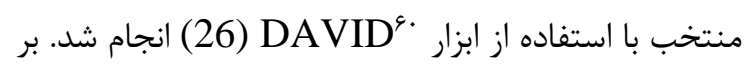
مبناى خروجى ابزار DAVID آنتولوزى زن و تحليل

\footnotetext{
${ }^{47}$ Tumor Size

${ }^{48}$ Node

${ }^{49}$ AJCC Stage

${ }^{50}$ Age of Diagnosis

${ }^{51}$ Histological Type

${ }^{52}$ Menopause Status

${ }^{53}$ Overall Survival (OS) Status

${ }_{54}^{54}$ Overall Survival (OS) Time

${ }^{55}$ Progression Free Interval (PFI) Status

${ }^{56}$ Progression Free Interval (PFI) Time

${ }^{57} \mathrm{P}$-value

${ }^{58}$ Single-gene Survival Analysis

${ }^{59}$ Gene Enrichment Analysis

60 Database for Annotation, Visualization, and Integrated

Discovery (DAVID)
}

هميوشانى تويولوزيكى بr باعث تفكيك بهتر خوشهها از

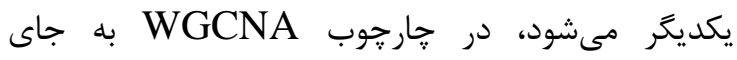

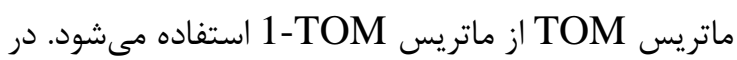

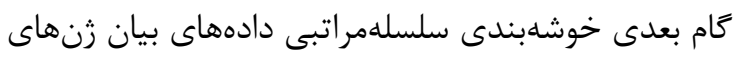

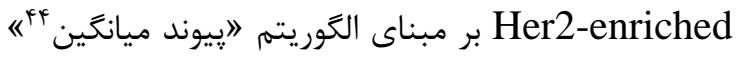

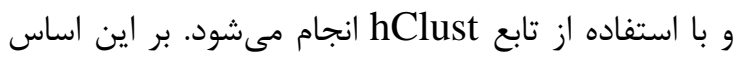

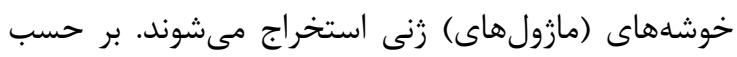

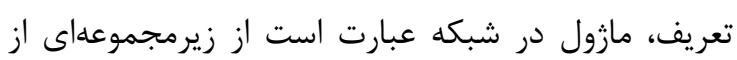

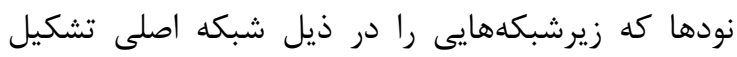

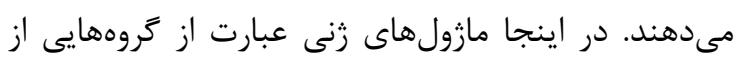

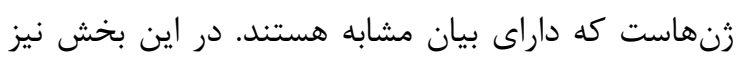

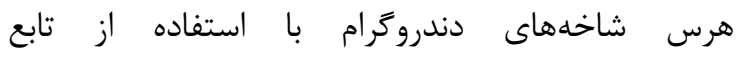
ائ cutreeDynamic

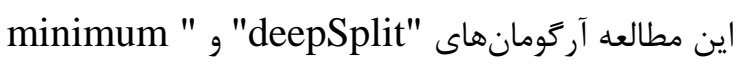
"cluster size

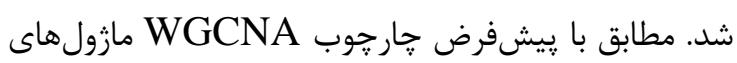

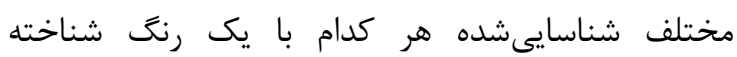

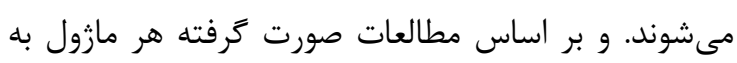

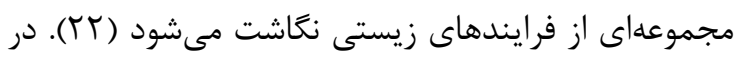

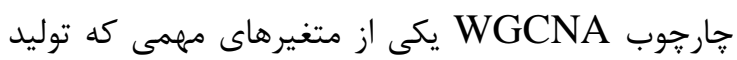
مىشود ME) Module Eigengene است كه مع معادل

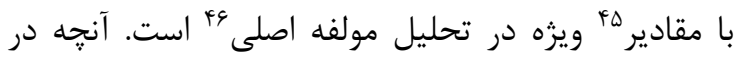

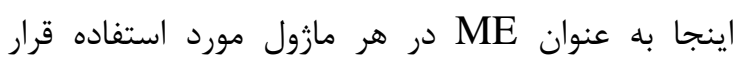
مى گيرد نخستين مولفه اصلى (PC1) است كه بيشترين

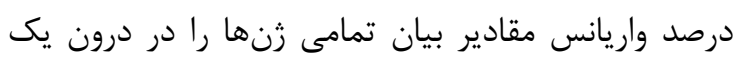

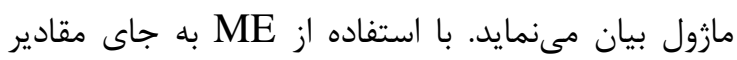

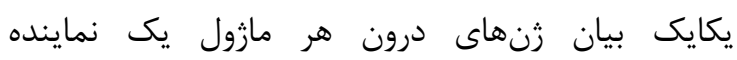

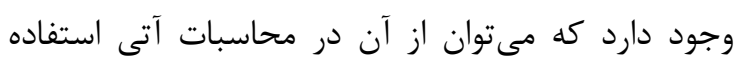

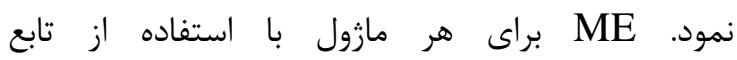
moduleEigengenes بE برخى مازولها بسيار به هم نزديك است مىتوان بر

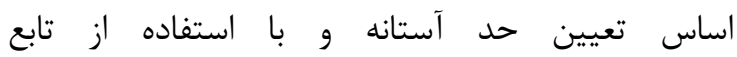
mergeCloseModules شناسايى مازولهاى مطلوب إنائ

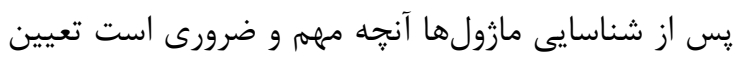

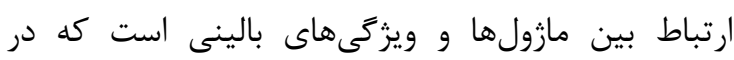

\footnotetext{
${ }^{43}$ TOM-based dissimilarity

${ }^{44}$ Average Linkage

${ }^{45}$ Eigenvalue

${ }^{46}$ Principal Component Analysis (PCA)
} 
كشف اشتباه\& كمتر از هـ • • براى تشخيص معنادارى فرايندها و مسيرهاى زيستى به عنوان حد آستانه تعريف شد.
مسيرهاى زيستى براى مازولهاى منتخب مورد بررسى

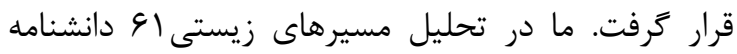

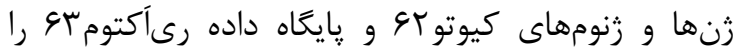
مورد بررسى قرار داديم. يى- مقدار كمتر از هـ • • • و نرخ

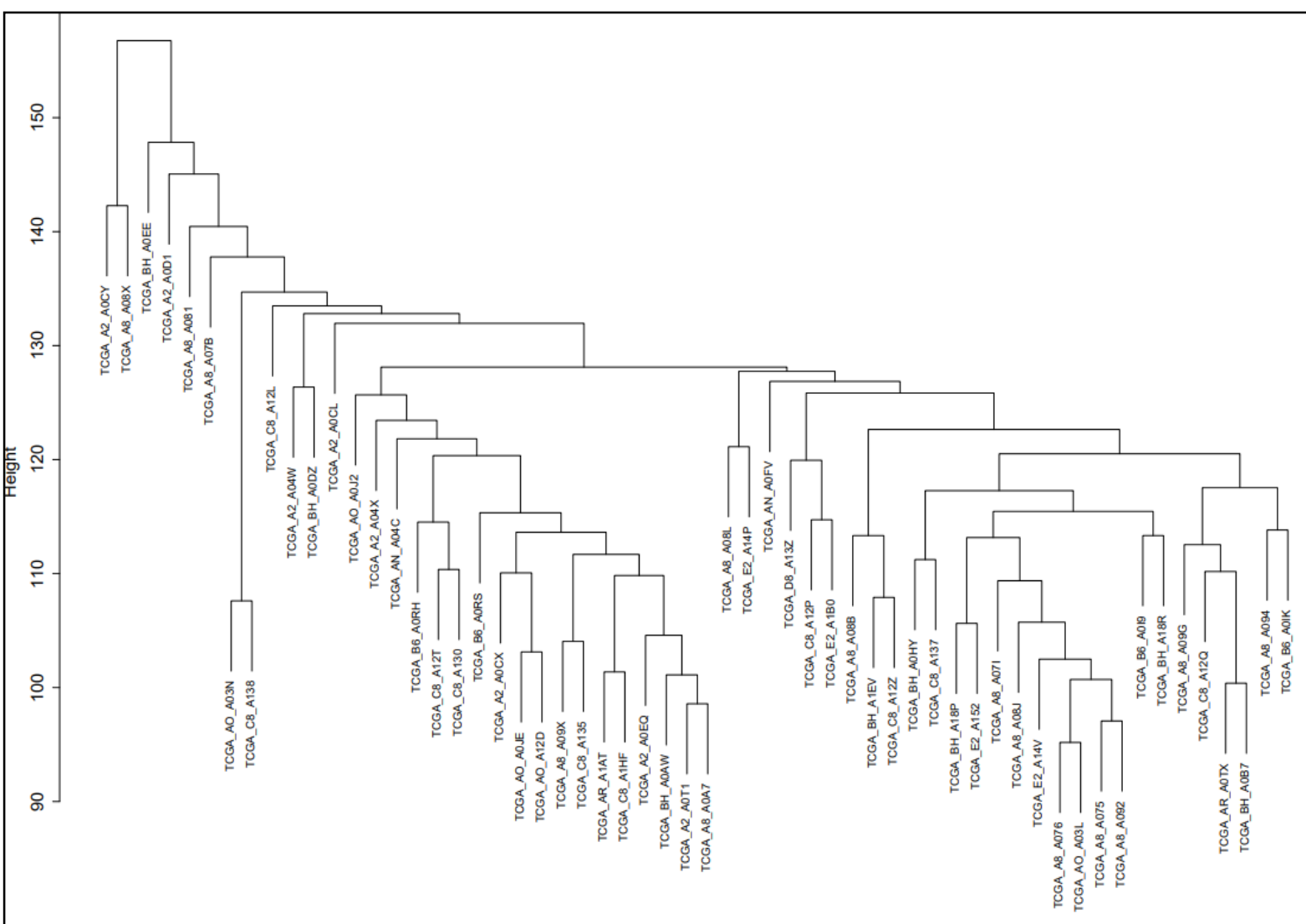

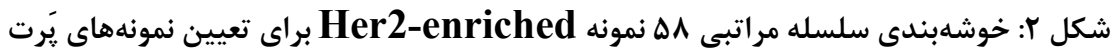

$$
\begin{aligned}
& \mathrm{R}^{2}>\cdot 1 \mathrm{\Lambda}-1 \\
& \text { r- بيشينه و ميانگين درجه در شبكه }
\end{aligned}
$$

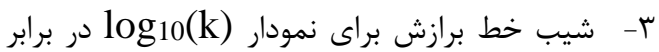
بايد تقريباً برابر ا- باشد. $\log _{10}(\mathrm{P}(\mathrm{k}))$

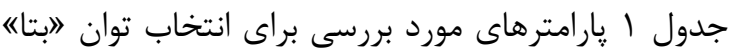

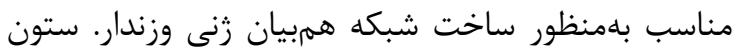
Power بيانگر مقادير مختلف بتا است. همجنين ارتباط است بلهورى كه .mean.k بيانگر مقدار ميانگين ارتباط و max.k بيانكر بيشنيه ارتباط است.

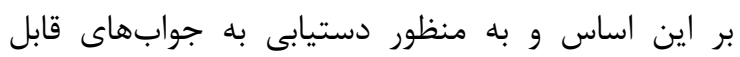
قبول، مقدار بتا برابر با م در نظر گرفته شد. با انتخاب بتابـ

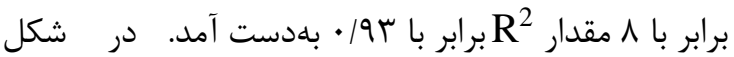

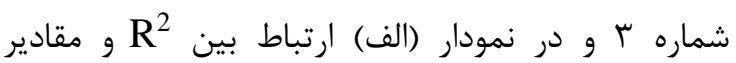
مختلف بتا و در نمودار (ب) ارتباط بين مقادير مختلف بتا با ميانگين درجه در شبكه Her2-enriched ارائه شده
بافتهها

شش مازول در شبكه همبيانى Her2-enriched همانطور كه ييش از اين بيان شد براى ساخت شبكو شيكه

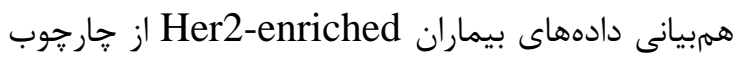
WGCNA آستانهى نرم، شبكه همبيانى Her2-enriched ساخته و شش مازول در آن شناسايى شد. در اين ميان گيارامتر بتا نقش مهمى در ايجاد خاصيت مقياس آزاد براى شبكه همبيانى ايفا مىنمايد. بر اين اساس ابتدا مجموعهاى از

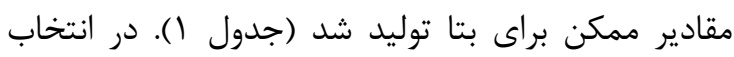
مقدار بتا بايد موارد ذيل را مدنظر قرار داد:

\footnotetext{
${ }^{61}$ Pathway Analysis

${ }^{62}$ Kyoto Encyclopedia of Genes and Genomes (KEGG)

${ }^{63}$ Reactome Database

${ }^{64}$ False Discovery Rate (FDR
} 
مازولهاى شكل گرفته در قبل و بعد از فرايند ادغام نمايش داده شده است.

رنغها در شكل شماره \& بيانكر مازولهاى زنى شناخته

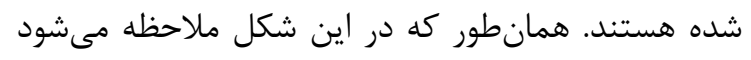

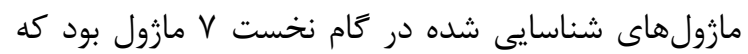
يس از فرايند ادغام به \& مازول كاهش پِيدا نمود.

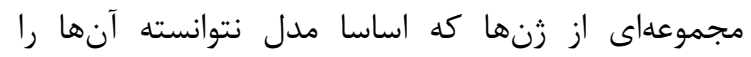

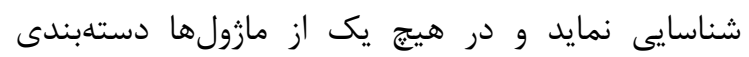
نشدهاند در مازول خاكسترى قرار مى تيرند.
است. در ادامه با استفاده از ماتريس بيان زن و مقدار بتاى انتخاب شده ماتريس مجاورت ساخته و سيس با استفاده

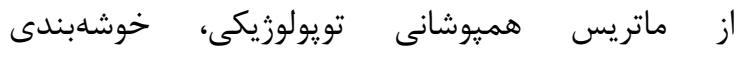

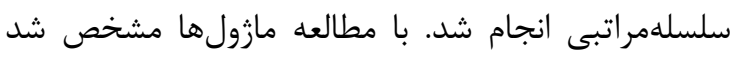
برخى از MEهاى مازولها بسيار به هم نزديك بوده كه

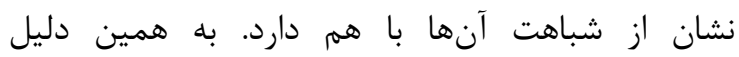

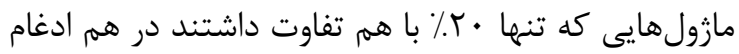

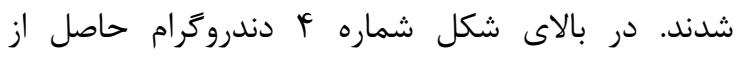

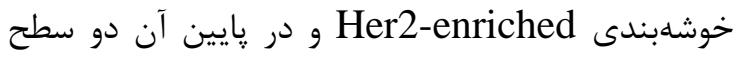

\begin{tabular}{|c|c|c|c|c|c|}
\hline Power & R.square & Slope & mean.k. & median.k. & max.k. \\
\hline 1 & 0.24 & 1.01 & 2001.55 & 1858.18 & 4410.73 \\
\hline 2 & 0.50 & -1.49 & 541.87 & 443.57 & 1927.70 \\
\hline 3 & 0.78 & -2.02 & 188.37 & 129.54 & 997.66 \\
\hline 4 & 0.81 & -2.18 & 77.81 & 43.24 & 585.72 \\
\hline 5 & 0.82 & -2.18 & 36.58 & 16.35 & 368.06 \\
\hline 6 & 0.80 & -2.15 & 19.04 & 6.82 & 242.64 \\
\hline 7 & 0.78 & -2.04 & 10.76 & 3.11 & 165.82 \\
\hline 8 & 0.93 & -1.73 & 6.51 & 1.51 & 121.47 \\
\hline 9 & 0.95 & -1.72 & 4.18 & 0.77 & 102.79 \\
\hline 10 & 0.96 & -1.67 & 2.82 & 0.41 & 88.05 \\
\hline 12 & 0.98 & -1.58 & 1.45 & 0.13 & 66.40 \\
\hline 13 & 0.98 & -1.54 & 1.09 & 0.08 & 58.69 \\
\hline 14 & 0.98 & -1.51 & 0.85 & 0.04 & 52.33 \\
\hline 15 & 0.98 & -1.47 & 0.67 & 0.03 & 46.90 \\
\hline
\end{tabular}

ستون Mean.k. بيانكَ مقدار ميانغَين ارتباط و max.k. بيانكر بيشنيه ارتباط است.
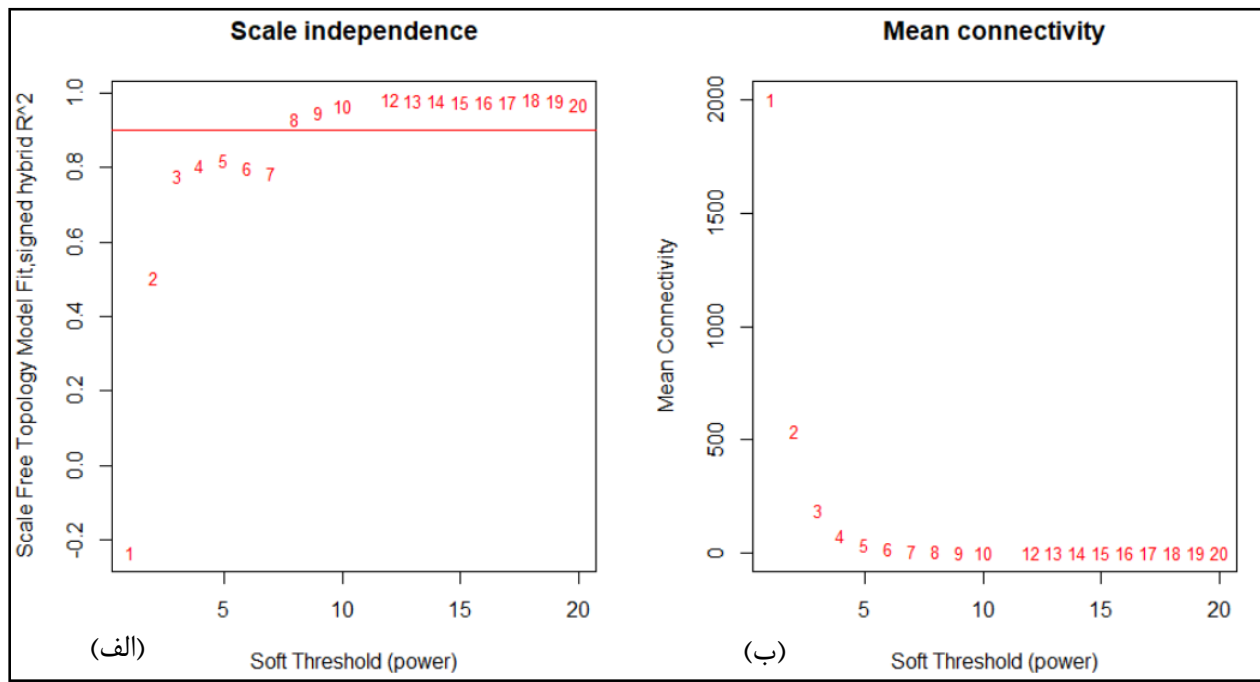

شكل r: نتايج بررسى و تحليل تويولوزى شبكه Her2-enriched بر اساس مقادير مختلف بتا

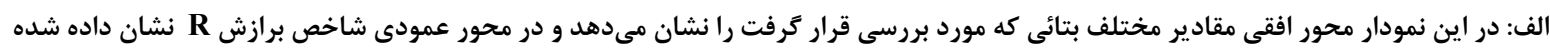

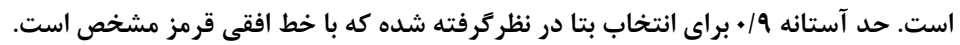

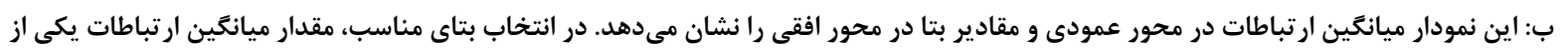

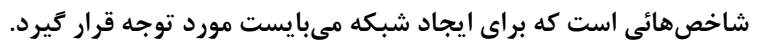




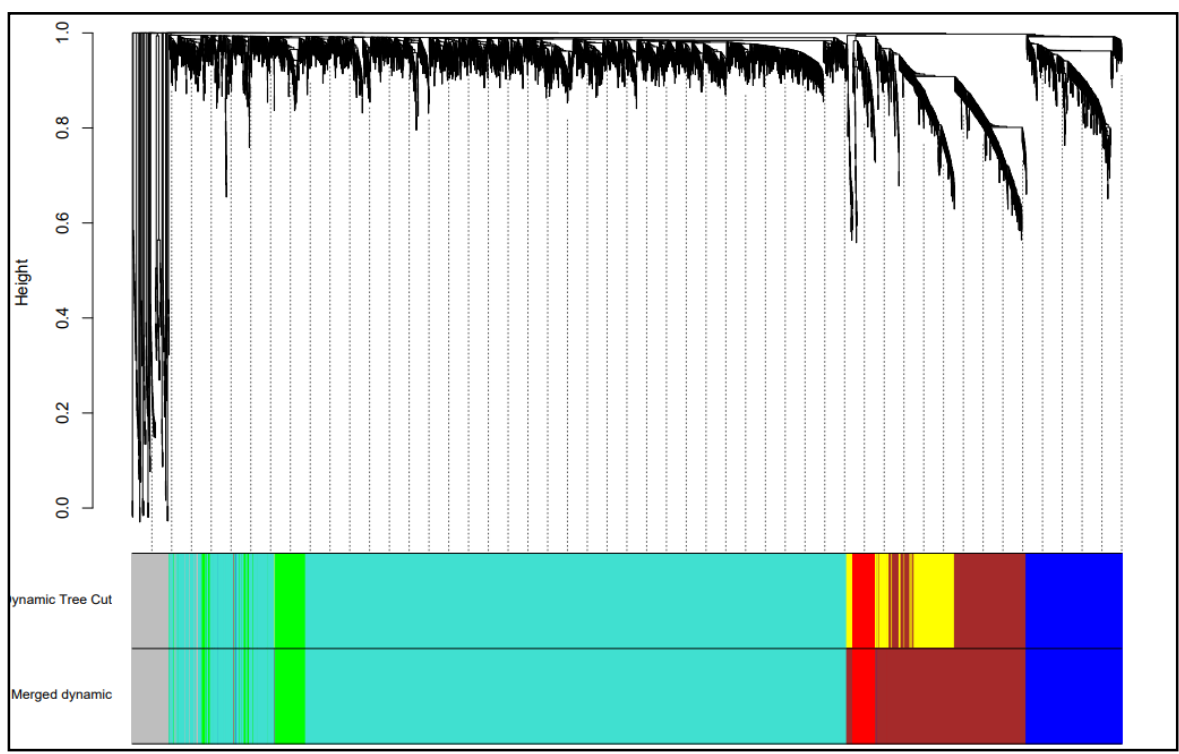

Her2-eriched شكل rا: دندروترام رنى

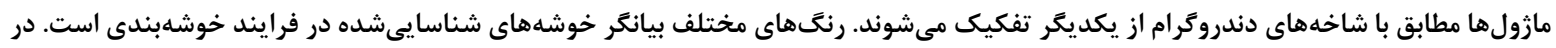

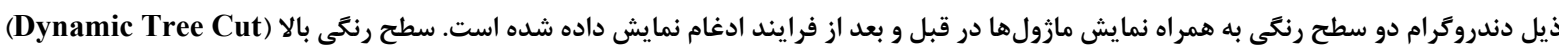

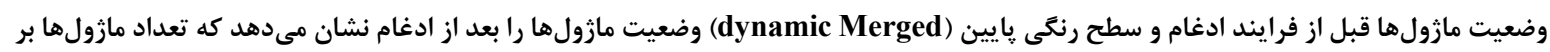

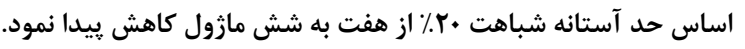

لنف نودهاى درگير با تومور" رابطه مثبت (TF/•) و يى - مقدار 1 • • • • • رابطه م عنادارى داشت. تحليل بقاء: از مدل رگرسيون كاكس براى تعيين تاثير هر مازول به عنوان متغير مستقل بر زمان و رويداد بقاى كلى به عنوان متغيرهاى وابسته در بيماران مبتلا به سرطان استفاده شد. بر اين اساس، از ME هر مازول به عنوان نماينده در رگرسيون كاكس استفاده كرديم كه از ميان مازولها دو مازول فيروزهاى و سبز با يى - مقدارهاى

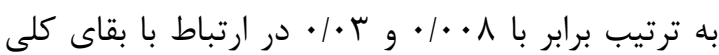

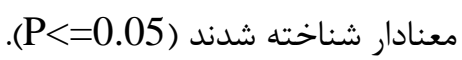
در جدول شماره r نتايج آناليز كاكس ارائه شده است. بر مبناى آنجه در جدول r ارائه شده است مقدار نسبت مخاطرهه $9 \Delta$ براى مازولهاى فيروزهاى و سبز به ترتيب برابر

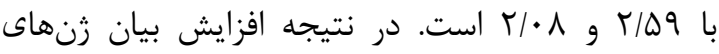
موجود در اين دو مازول باعث ييشآگهى بد به نسبت به بقاى كلى در بيماران گروه Her2-enriched مىشود. به عبارت بهتر افزايش بيان زنهاى مازول فيروزهاى و

${ }^{65}$ Hazard Ratio (HR)

${ }^{66}$ Poor Prognosis
شناسايى مازولهاى موثر بر پِيش آتمهى ارتباط بين مازولها و ويزگىهاى بالينى: امكان بررسى ارتباط بين يروفايل بيان زن بيماران و صفات

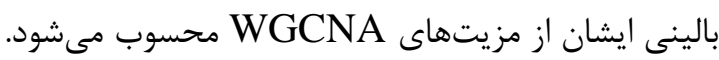

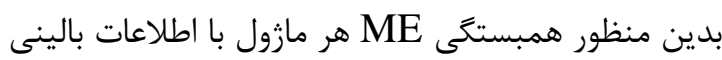
بيماران مورد مطالعه و بررسى قرار مى يزوهش مجموعا • ا ويزگكى بالينى و ياتولوزيكى از بيماران مبتلا به Her2-enriched اطلس رنوم سرطان استخراج و همبستگى آنها با ME هر مازول با استفاده از ضريب بيرسون محاسبه شد. نتيجه محاسبهى اين همبستكى در شكل شماره ه ارائه شده است. در اين راستا، مازول سبز با "اسن بيماران در زمان تشخيص

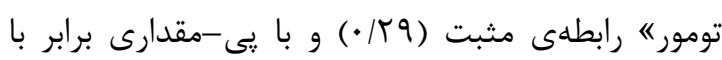

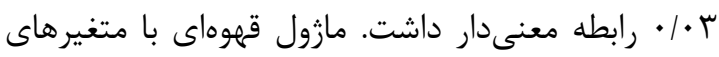

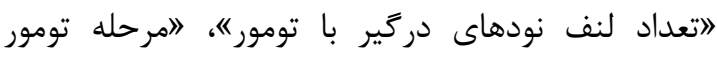
بيمار"، و "وضعيت بازه عارى از يِيشرفت توموره به ترتيب با بيى-مقدارهاى ץ.|•، ه•/• و r.|• رابطه معنادار داشت. همجنين مازول قرمز با متغير التعداد 
زيستى معنادار و مرتبطى با زنهاى موجود در اين مازول

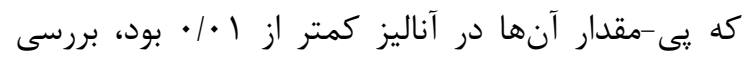

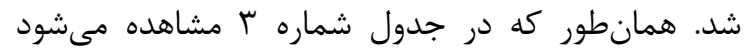

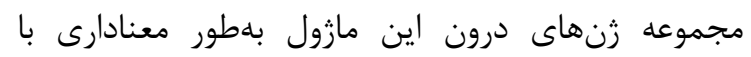
transcription, DNA-" فرايندهاى زيستى همجنى mRNA " "protein sumoylation" "templated intracellular protein " و " export from nucleus "transport mediated Ubiquitin" مسيرهاى زيستى "مEGG " و و "RNA degradation"lysis زن هاى موجود در مازول فيروزهاى معنادار شدند.
سبز باعث كاهش بقاى بيماران اين زيركروه از سرطان

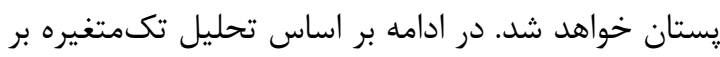

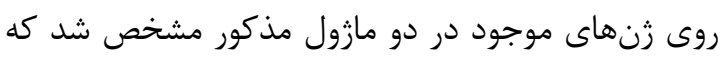

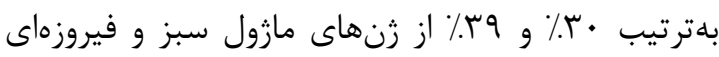
در ارتباط با بقاى كلى با آستانه ه•• معنادار هستند

$$
\text { (يوست تكميلى (). (يوس) }
$$

تحليل غنى سازى عملكردى زنهاى مازول ييش آتَهى

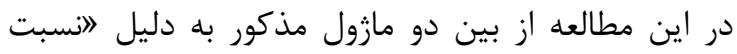

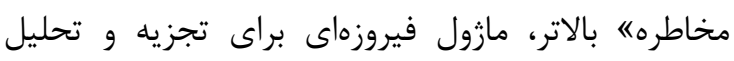

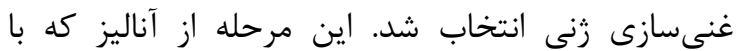

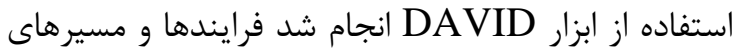

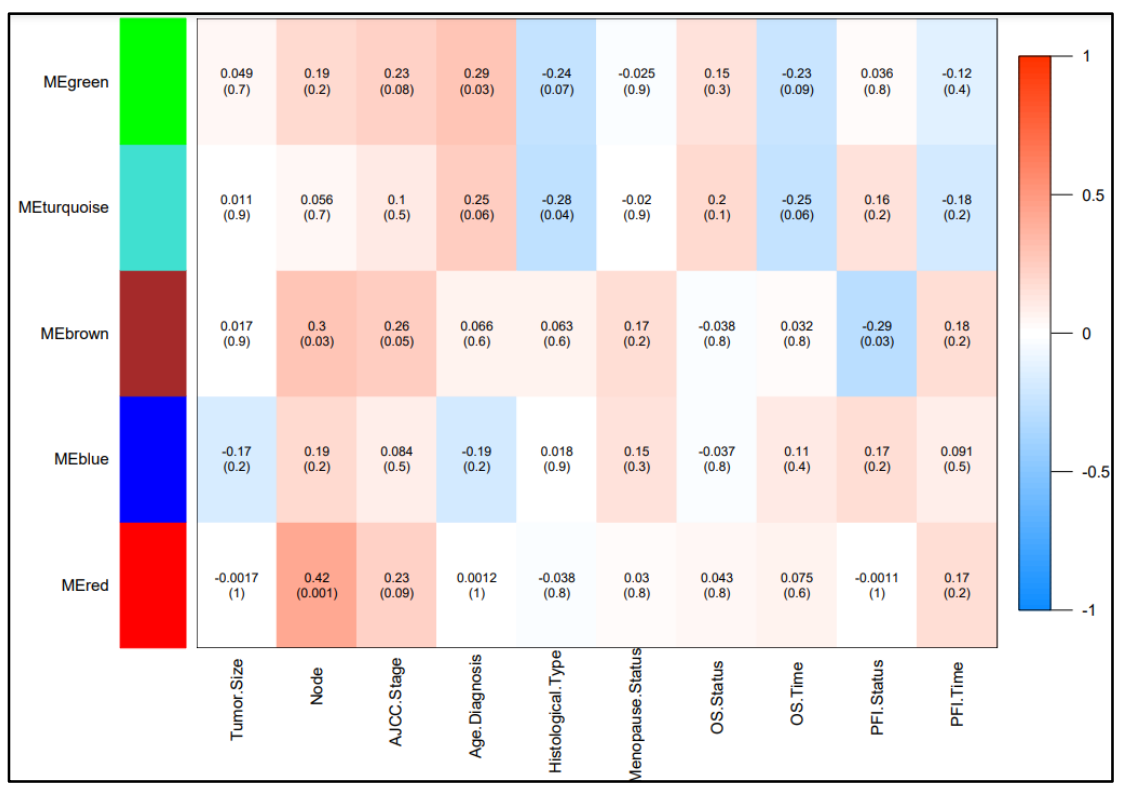

$$
\text { شكل ₹: ارتباط بين مازولها و متغيرهاى بالينى }
$$

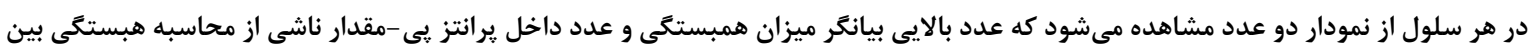

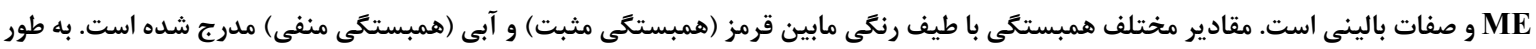

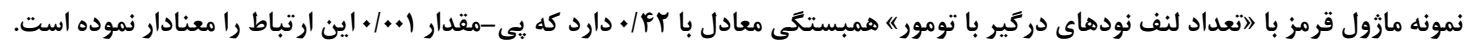

جدول r: نتايج اجراى كاكس بر روى ME مازولهاى شناسايى شده

\begin{tabular}{lcccc}
\hline \multirow{2}{*}{ Module Name } & \multirow{2}{*}{ No.Genes } & \multicolumn{3}{c}{ Overall Survival } \\
\cline { 3 - 5 } & & HR & P-value & CI \\
\hline Brown & 796 & 1.05 & 0.9 & $0.59-1.87$ \\
Turquoise & 3178 & 2.59 & 0.008 & $1.23-5.47$ \\
Blue & 485 & 0.89 & 0.7 & $0.49-1.60$ \\
Green & 213 & 2.08 & 0.03 & $1.04-4.14$ \\
Red & 117 & 1.14 & 0.7 & $0.63-2.05$ \\
Grey & 211 & - & - & - \\
\hline
\end{tabular}


جدول r: عناوين تفسير كاركردى در مازول فيروزهاى

\begin{tabular}{|c|c|c|c|c|c|}
\hline $\begin{array}{l}\text { Functional Annotation } \\
\text { Term }\end{array}$ & $\begin{array}{l}\text { Coun } \\
\mathrm{t}\end{array}$ & FDR & Functional Annotation Term & $\begin{array}{c}\text { Coun } \\
t\end{array}$ & FDR \\
\hline GO-Biological Process (BP) & & & GO-Molecular Function (MF) & & \\
\hline protein sumoylation & 19 & 2.39E-06 & protein binding & 315 & $2.30 \mathrm{E}-11$ \\
\hline $\begin{array}{l}\text { nuclear-transcribed mRNA } \\
\text { poly(A) tail shortening }\end{array}$ & 8 & 0.006 & poly(A) RNA binding & 69 & $7.12 \mathrm{E}-08$ \\
\hline mRNA export from nucleus & 13 & 0.006 & DNA binding & 74 & 0.003 \\
\hline DNA duplex unwinding & 9 & 0.006 & nucleotide binding & 25 & 0.004 \\
\hline transcription, DNA-templated & 82 & 0.006 & ATP binding & 67 & 0.004 \\
\hline intracellular transport of virus & 9 & 0.012 & helicase activity & 11 & 0.007 \\
\hline intracellular protein transport & 19 & 0.012 & $\begin{array}{l}\text { ATP-dependent helicase } \\
\text { activity }\end{array}$ & 7 & 0.007 \\
\hline tRNA export from nucleus & 7 & 0.032 & ubiquitin protein ligase binding & 21 & 0.007 \\
\hline regulation of glucose transport & 7 & 0.034 & chromatin binding & 25 & 0.010 \\
\hline $\begin{array}{l}\text { mRNA splicing, via } \\
\text { spliceosome }\end{array}$ & 17 & 0.042 & $\begin{array}{l}\text { ATP-dependent DNA helicase } \\
\text { activity }\end{array}$ & 7 & 0.010 \\
\hline protein transport & 24 & 0.047 & nucleic acid binding & 46 & 0.016 \\
\hline GO-Cellular Component & & & DNA helicase activity & 6 & 0.016 \\
\hline nucleoplasm & 168 & $1.65 \mathrm{E}-26$ & ligase activity & 19 & 0.016 \\
\hline cytoplasm & 200 & 4.02E-09 & RNA binding & 30 & 0.016 \\
\hline nucleus & 203 & $1.29 \mathrm{E}-08$ & $\begin{array}{l}\text { nuclear localization sequence } \\
\text { binding }\end{array}$ & 6 & 0.027 \\
\hline nucleolus & 50 & $1.01 \mathrm{E}-05$ & $\begin{array}{l}\text { transcription coactivator } \\
\text { activity }\end{array}$ & 17 & 0.036 \\
\hline nuclear pore & 12 & $1.56 \mathrm{E}-04$ & $\begin{array}{l}\text { ATP-dependent RNA helicase } \\
\text { activity }\end{array}$ & 8 & 0.051 \\
\hline membrane & 91 & $1.89 \mathrm{E}-04$ & zinc ion binding & 49 & 0.055 \\
\hline cytosol & 118 & 0.005 & KEGG Pathway & & \\
\hline nuclear membrane & 17 & 0.014 & Ubiquitin mediated proteolysis & 13 & 0.020 \\
\hline chromosome & 11 & 0.016 & RNA degradation & 11 & 0.005 \\
\hline
\end{tabular}

بيشترين درجه ارتباط با ساير زنها شناسايى شد كه يكى از آنها خاكسترى و غيرقابل استفاده بود. در تحليل انجام

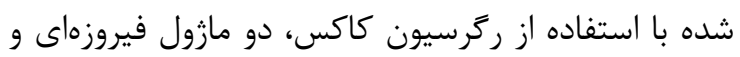

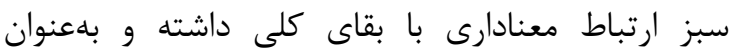

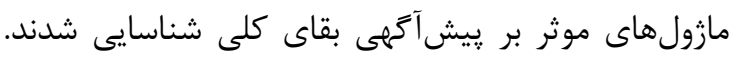

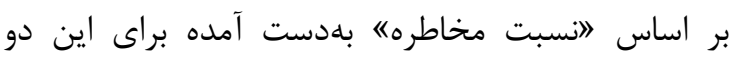

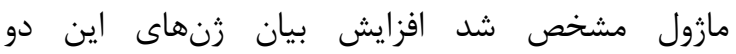

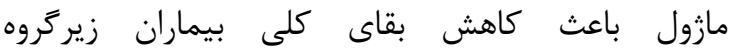
Her2-enriched "نسبت مخاطرهه در مازول فيروزهاى، زنهاى درون اين مازول در ارتباط با فرايندها و مسيرهاى زيستى مورد

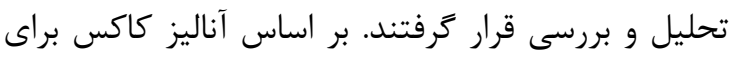

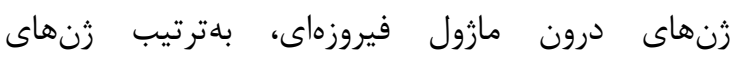
و KANSL3 PRRC2B،PPP1R26، CHAMP1

$$
\text { ANAPC2 به عنوان ه زن مهم شناسايى شدند. CHAMPI }
$$

در اين مطالعه از WGCNA براى تحليل دادههاى بيان mRNA

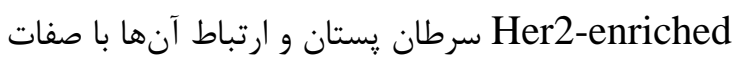
و ويزَى هاى بالينى استفاده شد. نمونههاى سرطان

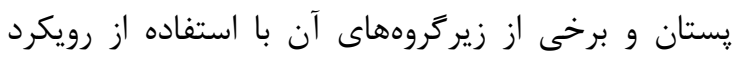

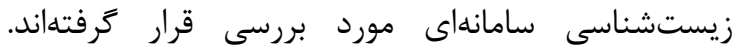

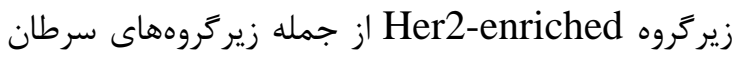

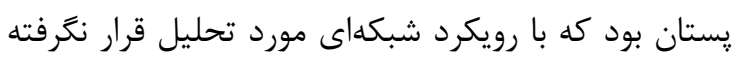

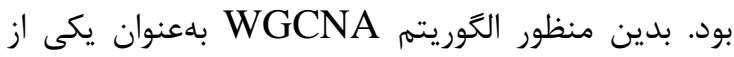
جارجوبهايى كه مبتنى بر روشهاى بدون نظارت اجرا

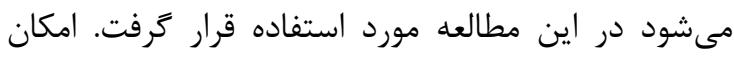

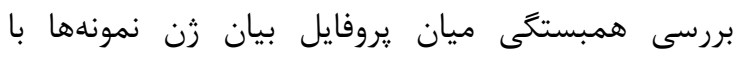

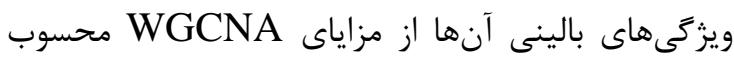

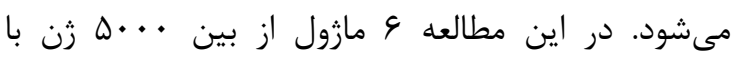


اما به طور كلى مطالعات كمى در مورد اين زنها در

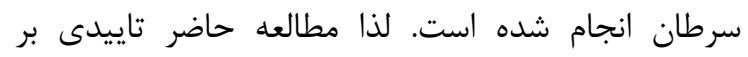

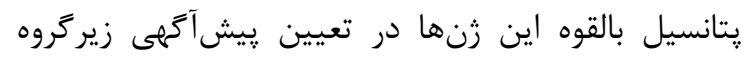

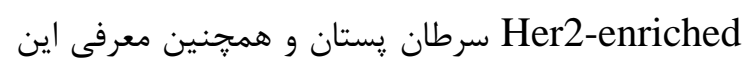

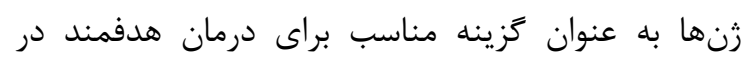

$$
\text { سرطان يستان است. }
$$

بعضى از مطالعات كه در زمينه استفاده از شبكههاى هم است

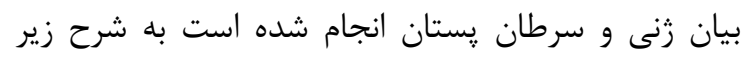

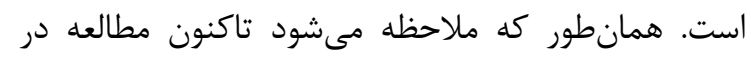

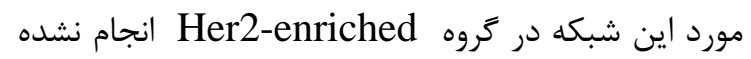

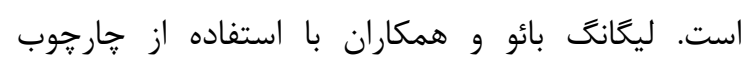
WGCNA

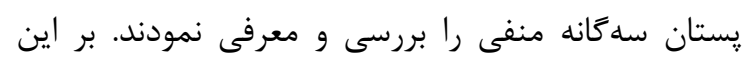

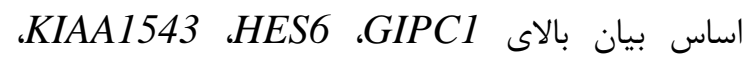
PنAN و MYLK2

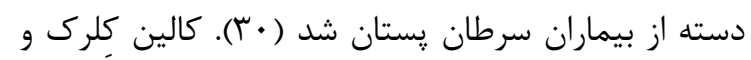

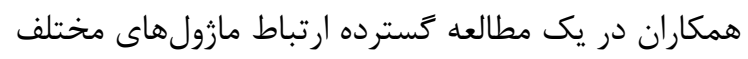

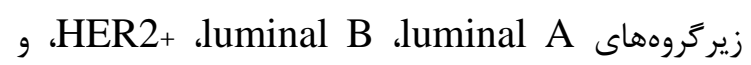
ر ا با صفات بالينى از جمله بقاى كلى مورد

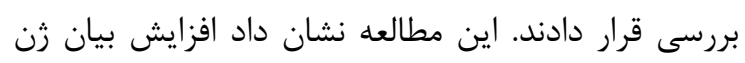

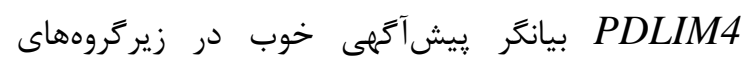

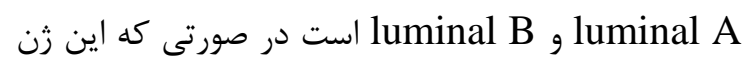

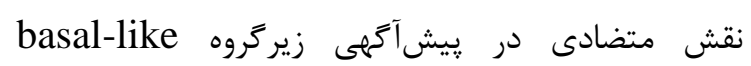
دارد. FOXM1 يكى از زنهايى است كه در اين مطالعه

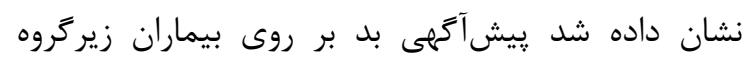
luminal B

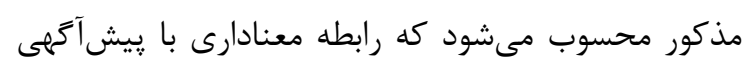

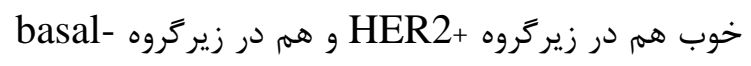

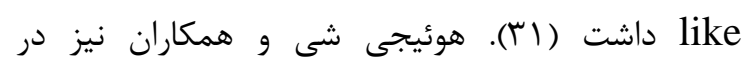

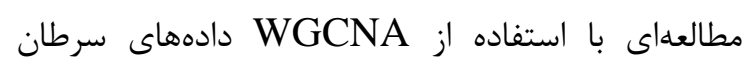

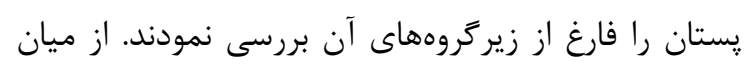

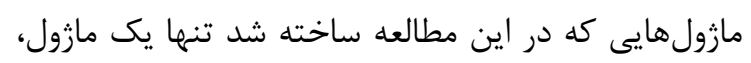

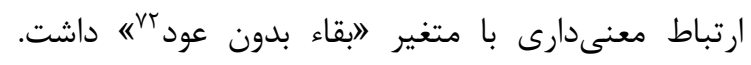
ايشان ·ل زن كليدى شامل CCNB2، KIF4A FOXM1 ASPM CDC20 PRC1 PUTG1 NUSAP1 انتخاب و آنها را با رويكرد بقاى تكزنى تحليل نمودند.

${ }^{71}$ Poor Overall Survival

${ }^{72}$ Relapse Free Survival
بر مبناى تحليل آنتولوزى زنى بيشتر زنهاى مازول

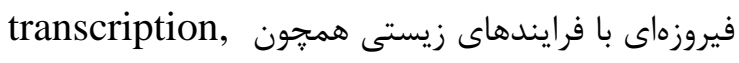
protein ، (GO:0006355) DNA-templated intracellular ،(GO:0015031) transport protein ،GO:0006886) protein transport mRNA export ،GO:0016925) sumoylation (GO:0006406) from nucleus داشتهاند. همجنين زنهاى اين مازول ارتباط معنادارى با رتباط مسيرهاى زيستى همجيون Ubiquitin mediated RNA degradation و (hsa04120) proteolysis (hsa03018)

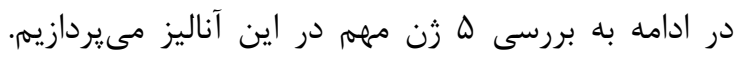
CHAMP1 نقش دارد و مطالعات نشان داده است كه در ايجاد برخى دارئ

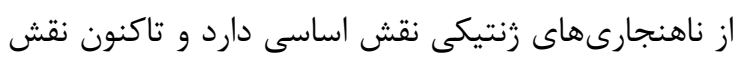

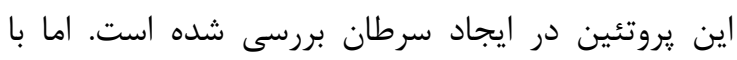

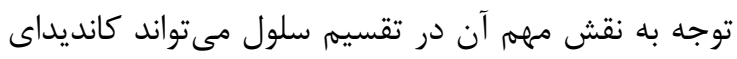
مطالعات آتى در زمينه سرطان باشد. يك زيرواحد تنظيم كنندهى يروتئين فسفاتاز

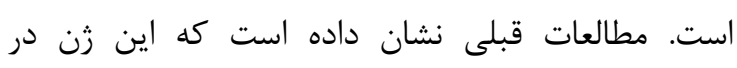

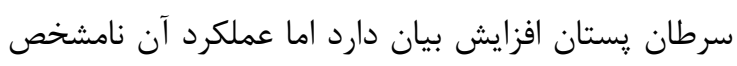

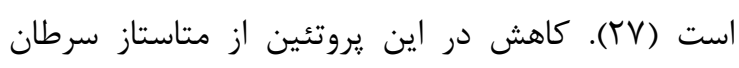

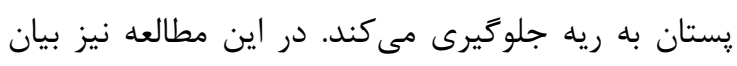

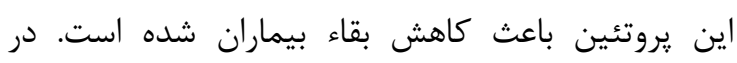

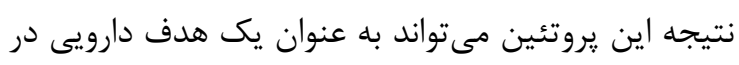
نظر كرفته شود.

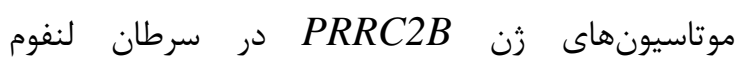

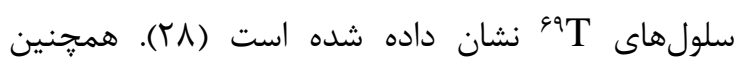

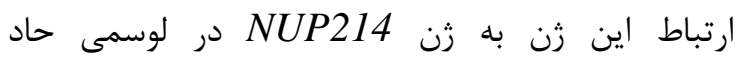

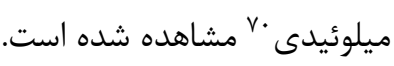
KANSL3

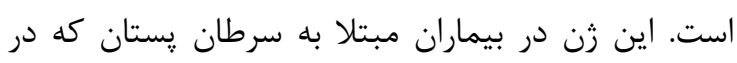

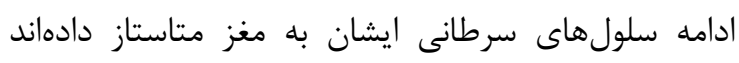

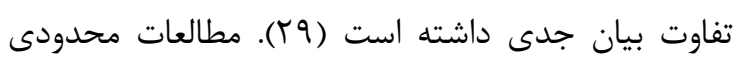

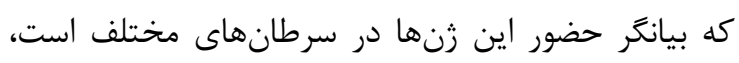

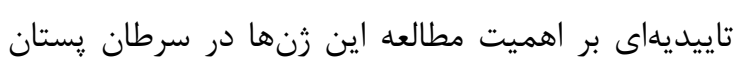

\footnotetext{
${ }^{67}$ Microtubule

${ }^{68}$ Kinetochore

${ }^{69} \mathrm{~T}$ Cell Lymphoma

${ }^{70}$ Acute myeloid leukemia (AML)
} 
عملكرد زنهاى شناسايى شده و همجنين مطالعهى

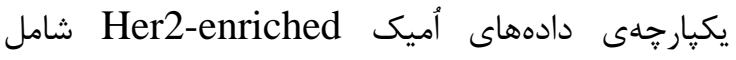

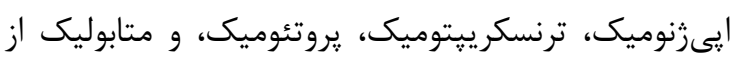
كامهاى بعدى اين مطالعه محسوب مى شودئ تشكر و قدردانى اين مقاله مستخرج از رساله دكترى مهندسى كامبيوتر با

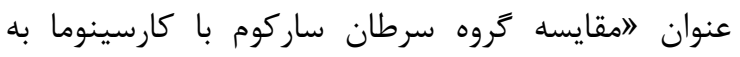

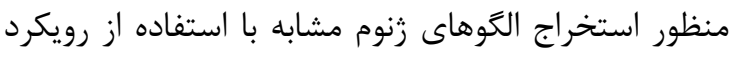
زيستشناسى سامانهاى" مصوب يزوهشكده برق و فناورى

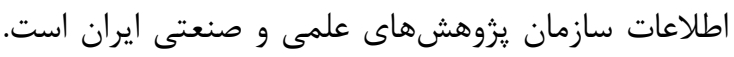

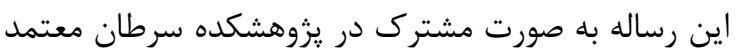

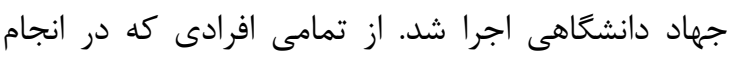

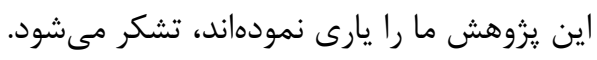

تعارض منافع

نويسندگان اعلام مىدارند كه هيج تعارض منافعى در يزوهش حاضر وجود ندارد.

\section{References}

1. Global cancer statistics 2020 [Internet]. International Agency for Research on Cancer. 2020. Available from: https://gco.iarc.fr/today.

2. Makki J. Diversity of breast carcinoma: histological subtypes and clinical relevance. Clinical Medicine Insights:Pathology. 2015; 8:CPath-S31563.

3. Rakha EA, El-Sayed ME, Green AR, Lee AH, Robertson JF, Ellis IO. Prognostic markers in triple-negative breast cancer. Cancer. 2007; 109(1):25-32.

4. Aysola K, Desai A, Welch C, Xu J, Qin Y, Reddy V, Matthews R, Owens C, Okoli J, Beech DJ, Piyathilake CJ. Triple negative breast cancer- an overview. Hereditary genetics: current research. 2013; 2013(Suppl 2).

5. Dent R, Trudeau M, Pritchard KI, Hanna WM, Kahn HK, Sawka CA, Lickley LA, Rawlinson
نتايج اين تحليل نشان داد تمامى اين زنها با "ابقاء بدون عوده همبستگى معنادارى داشتند (Yr).

\section{نتيجهكيرى}

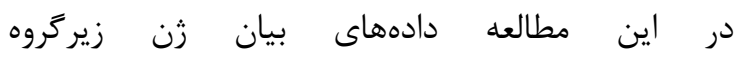
Her2-enriched استفاده از جار جوب WGCNA مورد بررسى قرار گرفت.

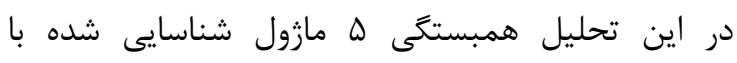

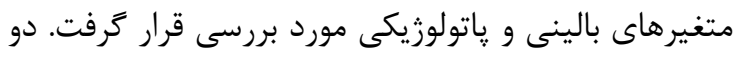

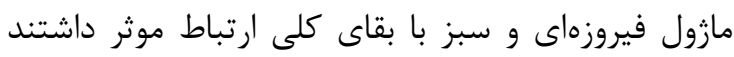

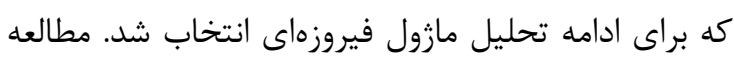
ما نشان داد افزايش بيان زنهاى مازول فيروزهاى باعث

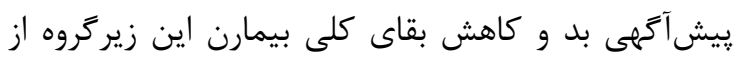

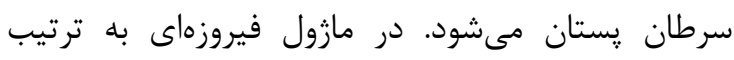
زنهاى CHAMP1، PPP1R26، PRRC2B،

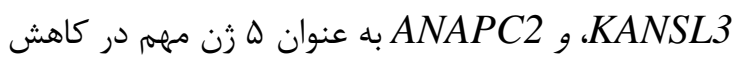
بقاى كلى شناسايى شدند. در اين مطالعه فهرستى از زن رنها

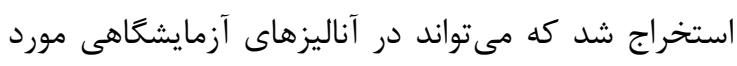

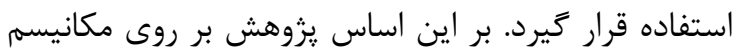

E, Sun P, Narod SA. Triple-negative breast cancer: clinical features and patterns of recurrence. Clinical cancer research. 2007; 13(15):4429-34.

6. Plevritis SK, Munoz D, Kurian AW, Stout NK, Alagoz O, Near AM, Lee SJ, Van Den Broek JJ, Huang X, Schechter CB, Sprague BL. Association of screening and treatment with breast cancer mortality by molecular subtype in US women, 2000-2012. Jama. 2018; 319(2):154-64.

7. Vaz-Luis I, Winer E, Lin N. Human epidermal growth factor receptor-2-positive breast cancer: does estrogen receptor status define two distinct subtypes? Annals of Oncology. 2013; 24(2): 283-91.

8. Langfelder P, Horvath S. WGCNA: an R package for weighted correlation network analysis. BMC bioinformatics. 2008; 9(1): 1-3 
9. Zhang H, Zhao X, Wang M, Ji W. Key modules and hub genes identified by coexpression network analysis for revealing novel biomarkers for larynx squamous cell carcinoma. Journal of Cellular Biochemistry. 2019; 120(12): 19832-40.

10. Tian H, Guan D, Li J. Identifying osteosarcoma metastasis associated genes by weighted gene co-expression network analysis (WGCNA). Medicine. 2018; 97(24).

11. Qiu J, Du Z, Wang Y, Zhou Y, Zhang Y, Xie $\mathrm{Y}$, Lv Q. Weighted gene co-expression network analysis reveals modules and hub genes associated with the development of breast cancer. Medicine. 2019; 98(6).

12. Zhang C, Sun Q. Weighted gene coexpression network analysis of gene modules for the prognosis of esophageal cancer. Journal of Huazhong University of Science and Technology [Medical Sciences]. 2017; 37(3):319-25.

13. Zhang X, Feng H, Li Z, Li D, Liu S, Huang H, Li M. Application of weighted gene coexpression network analysis to identify key modules and hub genes in oral squamous cell carcinoma tumorigenesis. OncoTargets and therapy. 2018; 11:6001.

14. Wang T, Wu B, Zhang X, Zhang M, Zhang S, Huang W, Liu T, Yu W, Li J, Yu X. Identification of gene coexpression modules, hub genes, and pathways related to spinal cord injury using integrated bioinformatics methods. Journal of cellular biochemistry. 2019; 120(5): 6988-97.

15. Zhou X, Zhen X, Liu Y, Cui Z, Yue Z, Xu A, Han J. Identification of Key Modules, Hub Genes, and Noncoding RNAs in Chronic Rhinosinusitis with Nasal Polyps by Weighted Gene Coexpression Network Analysis. BioMed Research International. 2020 Jan 23; 2020.

16. Guo SM, Wang JX, Li J, Xu FY, Wei Q, Wang HM, Huang HQ, Zheng SL, Xie YJ, Zhang C. Identification of gene expression profiles and key genes in subchondral bone of osteoarthritis using weighted gene coexpression network analysis. Journal of cellular biochemistry. 2018; 19(9): 7687-95.

17. Li W, Wang L, Wu Y, Yuan Z, Zhou J. Weighted gene co-expression network analysis to identify key modules and hub genes associated with atrial fibrillation. International journal of molecular medicine. 2020; 45(2):401-16.

18. Network CGA. Comprehensive molecular portraits of human breast tumours. Nature. 2012; 490(7418):61.
19. Liu J, Lichtenberg T, Hoadley KA, Poisson LM, Lazar AJ, Cherniack AD, Kovatich AJ, Benz CC, Levine DA, Lee AV, Omberg L. An integrated TCGA pan-cancer clinical data resource to drive high-quality survival outcome analytics. Cell. 2018; 173(2):400-16.

20. Mounir M, Lucchetta M, Silva TC, Olsen C, Bontempi G, Chen X, Noushmehr H, Colaprico A, Papaleo E. New functionalities in the TCGAbiolinks package for the study and integration of cancer data from GDC and GTEx. PLoS computational biology. 2019; 15(3): e1006701.

21. Song L, Langfelder P, Horvath S. Comparison of co-expression measures: mutual information, correlation, and model based indices. BMC bioinformatics. 2012; 13(1): 121.

22. Zhang B, Horvath S. A general framework for weighted gene co-expression network analysis. Statistical applications in genetics and molecular biology. 2005; 4(1).

23. Therneau TM, Grambsch PM. Statistics for biology and health. Modeling survival data: extending the Cox model: Springer-Verlag. 2000; 87-152.

24. Kassambara A, Kosinski M, Biecek P, Fabian S. Drawing Survival Curves using "ggplot2". $\mathrm{R}$ package version 0.2. 2018;2.

25. Blighe K. RegParallel: Standard regression functions in $\mathrm{R}$ enabled for parallel processing over large data-frames. bioconductor. 2019.

26. Sherman BT, Lempicki RA. Systematic and integrative analysis of large gene lists using DAVID bioinformatics resources. Nature protocols. 2009;4(1):44.

27. Zheng T, Lu M, Wang T, Zhang C, Du X. NRBE3 promotes metastasis of breast cancer by down-regulating E-cadherin expression. Biochimica et Biophysica Acta (BBA)Molecular Cell Research. 2018; 1865(12): 1869-77.

28. Donner I, Katainen R, Kaasinen E, Aavikko M, Sipilä LJ, Pukkala E, Aaltonen LA. Candidate susceptibility variants in angioimmunoblastic T-cell lymphoma. Familial cancer. 2019; 18(1): 113-9.

29. Mamoor S. The KAT8 regulatory NSL subunit complex subunit 2 (KANSL2) is overexpressed in brain metastatic breast cancer. 2020.

30. Bao L, Guo T, Wang J, Zhang K, Bao M. Prognostic genes of triple-negative breast cancer identified by weighted gene co-expression network analysis. Oncology letters. 2020; 19(1):127-38. 
31. Clarke C, Madden SF, Doolan P, Aherne ST, Joyce H, O'driscoll L, Gallagher WM, Hennessy BT, Moriarty M, Crown J, Kennedy S. Correlating transcriptional networks to breast cancer survival: a large-scale coexpression analysis. Carcinogenesis. 2013; 34(10):2300-8
32. Shi H, Zhang L, Qu Y, Hou L, Wang L, Zheng M. Prognostic genes of breast cancer revealed by gene co-expression network analysis. Oncology letters. 2017; 14(4): 453542. 